\title{
COMMUNICATION
}

Cite this: DOI: $10.1039 /$ xoxxooooox

\section{Efficient Methods for Enol Phosphate Synthesis Using Carbon-centred Magnesium Bases}

\author{
William J. Kerr, ${ }^{* a}$ David M. Lindsay, ${ }^{a}$ Vipulkumar K. Patel, ${ }^{b}$ and Muralikrishnan \\ Rajamanickam $^{a}$
}

Received ooth January 2012,

Accepted ooth January 2012

DOI: $10.1039 / \times 0 x x 00000 x$

www.rsc.org/

Efficient conversion of ketones into kinetic enol phosphates under mild and accessible conditions has been realised using the developed methods with di-tert-butylmagnesium and bismesitylmagnesium. Optimisation of the quench protocol resulted in high yields of enol phosphates from a range of cyclohexanones and aryl methyl ketones, with tolerance of a range of additional functional units.

\section{Introduction}

Versatile functional handles - groups which may be transformed into a range of different products - are highly prized, both in complex molecule synthesis in particular and synthetic organic chemistry in general. To this end, enol phosphates have often played a key role in the synthesis of natural products and biologically active compounds. ${ }^{1}$ The high stability of enol phosphates, in conjunction with their wideranging portfolio of derivatisations, ${ }^{2}$ such as within cross coupling processes, ${ }^{3}$ are key aspects of their preparative popularity. Although various synthetic methodologies have been developed to allow access to enol phosphates, ${ }^{4}$ the most convenient strategy consists of the deprotonation of an enolisable ketone using a strong base, followed by reaction of the subsequent metal enolate with a phosphoryl chloride. ${ }^{\text {a-ld }}$ Specifically, this procedure usually employs strong organolithium bases, such as lithium di-iso-propyl amide (LDA) at low temperature ($78{ }^{\circ} \mathrm{C}$ ), with the obvious attendant drawbacks in terms of functional group compatibility, energy efficiency, and competing side-reactions. ${ }^{5}$ Recently, however, we have reported the use of diaryl- and dialkylmagnesium bases $\mathbf{1}$ and $\mathbf{2}$, respectively, for the efficient formation of silyl enol ethers under mild conditions (Scheme 1). ${ }^{6}$ These diorganomagnesium species, readily prepared from their corresponding Grignard reagents, were found to function effectively as bases without presenting any nucleophilic reactivity towards the ketone substrates. Diaryl- and dialkylmagnesium bases $\mathbf{1}$ and $\mathbf{2}$ also displayed high levels of chemo- and regioselectivity in the deprotonation of a broad range of ketones, establishing an efficient process for the formation of silyl enol ethers under readily accessible conditions. In terms of reaction time, the use of $\mathrm{Mes}_{2} \mathrm{Mg} 1$ afforded high yields of the silyl enol ether products in

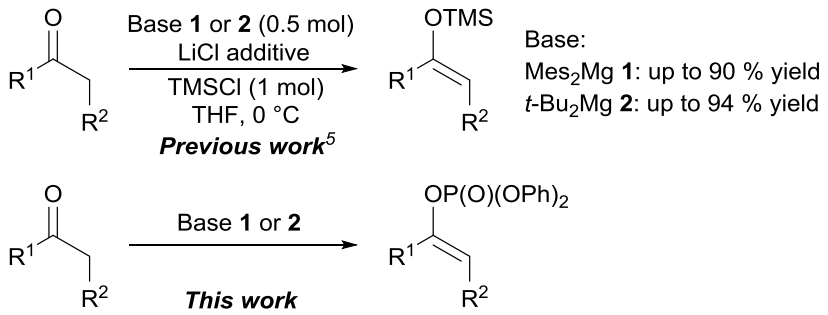

Scheme 1 Synthesis of silyl enol ethers using carbon-centred magnesium bases and proposed extension to enol phosphates.

$8 \mathrm{~h},{ }^{6 \mathrm{a}, \mathrm{b}}$ whereas the use of $t-\mathrm{Bu}_{2} \mathrm{Mg} 2$, a more reactive base, resulted in the same same levels of reactivity in only $1 \mathrm{~h} .{ }^{6 c}$ Encouraged by the efficacy of these carbon-centred magnesium bases in the preparation of silyl enol ethers, we proposed to extended their application to the synthesis of the related, but more versatile, enol phosphates under similarly mild conditions. Herein we report our studies on the use of diorganomagnesium bases $\mathbf{1}$ and $\mathbf{2}$ in the formation of enol phosphates. ${ }^{7}$

\section{Results and discussion}

The active magnesium bases were readily prepared from commercially available reagents. As shown in Scheme 2, dimesitylmagnesium 1 was prepared in a one-pot process involving the formation of the Grignard reagent from bromomesitylene, followed by disproportionation towards the diarylmagnesium species $\mathbf{1}$, induced by addition of 1,4-dioxane. The dialkylmagnesium base, di-tert-butylmagnesium $\mathbf{2}$, was readily prepared from the commercial Grignard reagent tert-butylmagnesium chloride in a similar manner. The two newly-formed bases were stored

$$
\begin{aligned}
& \operatorname{MesBr} \underset{\text { i) } \mathrm{Mg}, 3 \mathrm{~h}, \mathrm{THF}, 40^{\circ} \mathrm{C}}{\text { ii) 1,4-dioxane (1.05 eq.) }} \underset{\mathbf{1}}{\mathrm{Mes}_{2} \mathrm{Mg}}+\mathrm{MgBr}_{2} \cdot 1 \text {,4-dioxane } \\
& t \text {-BuMgCl } \underset{\mathbf{2}}{\stackrel{1,4-\text { dioxane }(1.05 \text { eq. })}{\mathrm{THF}}} \underset{\mathbf{2}}{\rightarrow-\mathrm{Bu}_{2} \mathrm{Mg}}+\mathrm{MgCl}_{2} \cdot \text { 1,4-dioxane }
\end{aligned}
$$

Scheme 2 Formation of carbon-centred bases. 
at room temperature under an argon atmosphere and were standardised ${ }^{8}$ prior to use.

With these bases in hand, we applied our previously optimised conditions for the formation of silyl enol ethers, using base $1^{6 \mathrm{~b}}$ with model substrate 3, and employing diphenylphosphoryl chloride as the phosphorus source. Lithium chloride was used as an additive, since this had previously been found to be beneficial in our studies on the formation of silyl enol ethers. ${ }^{6 a, c}$ Under these conditions (Entry 1, Table 1 ), the deprotonation of 4-tert-butylcyclohexanone $\mathbf{3}$ with base $\mathbf{1}$ afforded a disappointingly low $29 \%$ yield of the enol phosphate product 4 after a reaction time of $16 \mathrm{~h}$. Given the enhanced reactivity of the phosphoryl electrophile, shorter reaction times were also investigated. However, when the reactions were quenched after either 8 h (Entry 2, Table 1) or $1 \mathrm{~h}$ (Entry 3, Table 1), similar outcomes were observed. In continuing these optimisation studies, it was noted that, in the formation of silyl enol ethers, base $\mathbf{2}$ had exhibited a higher reactivity than base $\mathbf{1}$, allowing the transformation to be completed in only $1 \mathrm{~h}^{6 \mathrm{c}}$ In turn, applying the conditions used in Entry 3, Table 1 but with base 2 were rewarded with a much improved yield of $68 \%$ (Entry 5 , Table 1 ) of the enol phosphate product 4 . To further increase the reactivity of our diorganomagnesium bases, we investigated the use of $N, N^{\prime}$ dimethylpropyleneurea (DMPU) as an inexpensive and non-toxic additive which, more importantly, is known to be an excellent disaggregating agent for several organometallic species. ${ }^{9}$ Indeed, the use of this additive resulted in a higher level of conversion when combined with base 1 (Entry 4, Table 1), and, when subsequently applied to our more reactive base 2 , afforded a $75 \%$ yield of enol phosphate 4 (Entry 6, Table 1). Thus, this brief screening process allowed us to rapidly identify base $\mathbf{2}$ as being optimal for enol phosphate formation, and, more importantly, revealed that, as an additive, DMPU was more suitable than lithium chloride.

Table 1 Preliminary studies on enol phosphate formation using carboncentred magnesium bases

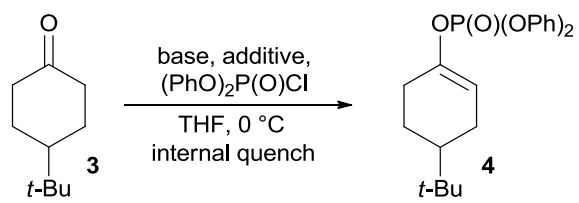

\begin{tabular}{ccccc} 
Entry & Base & Additive & Time & Yield $^{\mathrm{a}}$ \\
\hline $\mathbf{1}$ & $\mathrm{Mes}_{2} \mathrm{Mg} \mathrm{1}$ & $\mathrm{LiCl}$ & $16 \mathrm{~h}$ & $29 \%$ \\
$\mathbf{2}$ & $\mathrm{Mes}_{2} \mathrm{Mg} \mathrm{1}$ & $\mathrm{LiCl}$ & $8 \mathrm{~h}$ & $31 \%$ \\
$\mathbf{3}$ & $\mathrm{Mes}_{2} \mathrm{Mg} \mathrm{1}$ & $\mathrm{LiCl}$ & $1 \mathrm{~h}$ & $27 \%$ \\
$\mathbf{4}$ & $\mathrm{Mes}_{2} \mathrm{Mg} \mathrm{1}$ & $\mathrm{DMPU}$ & $1 \mathrm{~h}$ & $40 \%$ \\
$\mathbf{5}$ & $t-\mathrm{Bu}_{2} \mathrm{Mg} \mathrm{2}$ & $\mathrm{LiCl}$ & $1 \mathrm{~h}$ & $68 \%$ \\
$\mathbf{6}$ & $t-\mathrm{Bu}_{2} \mathrm{Mg} \mathbf{2}$ & $\mathrm{DMPU}$ & $1 \mathrm{~h}$ & $75 \%$
\end{tabular}

Reaction conditions: 4-tert-butylcyclohexanone $\mathbf{3}(1 \mathrm{mmol})$, base $\mathbf{1}$ or $\mathbf{2}(0.5$ $\mathrm{mmol})$, additive $(2 \mathrm{mmol})$, diphenylphosphoryl chloride $(1 \mathrm{mmol})$, THF (11 $\mathrm{mL}$ ), internal quench. ${ }^{\mathrm{a} A v e r a g e}$ isolated yield over two runs.

\section{Optimisation of enol phosphate formation using $t-\mathrm{Bu}_{2} \mathrm{Mg} 2$}

With both additive and base optimised to deliver a good isolated yield of enol phosphate 4, our attention turned to the other tuneable aspects of the reaction, and, in particular, the quench protocol, which is an extremely important parameter in reactions involving organometallic bases. So far we had employed an internal quench protocol (i.e. the ketone is slowly added to a solution of base and electrophile), as this was the optimised process in our previous studies on the formation of silyl enol ethers. ${ }^{6}$ However, this internal quench procedure requires the presence of the electrophile and the base together in the reaction vessel, and can increase the potential for by-product formation when used with reactive electrophiles. We thus opted to interrogate alternative quench procedures, starting with an exploration of a co-addition protocol (i.e. a solution of the ketone and electrophile is added to a solution of the base). In contrast to the internal quench, the co-addition protocol supplies an equimolar amount of ketone and electrophile to the reaction mixture, thus potentially reducing side reactions involving base and electrophile. As depicted in Scheme 3, use of this co-addition protocol afforded an improved $82 \%$ yield of enol phosphate 4 . Encouraged by this improvement, we extended these studies to the more practicallyconvenient reverse addition protocol, whereby base $\mathbf{2}$ was added dropwise into the reaction mixture already containing the electrophile, ketone, and additive. Pleasingly, under these revised conditions, we were able to isolate the enol phosphate product $\mathbf{4}$ in a high yield of $80 \%$. Although compared to the co-addition protocol the isolated yield was slightly lower, in terms of overall process time and ease of application, the reverse addition proved to be the most effective approach, and was utilised in subsequent optimisations.
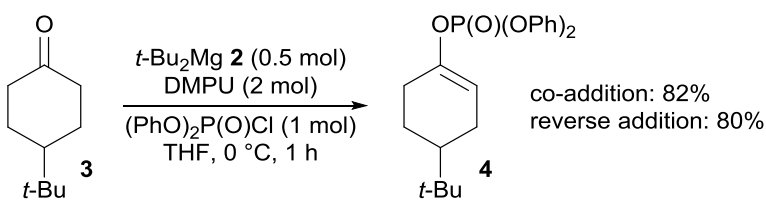

Scheme 3 Studies on the quench protocol using dialkylmagnesium base 2.

Next, our attention turned towards exploring more accessible, room temperature conditions. While higher reactivity of the base was expected at room temperature, the importance of the DMPU additive was also investigated at various loadings. Firstly, however, the deprotonation reaction was carried out at room temperature without any DMPU additive, and as observed in Entry 1, Table 2, the reaction afforded a good $84 \%$ yield of enol phosphate 4 . Addition of DMPU to the reaction mixture resulted in an increase in reactivity, as observed in

Table 2 DMPU loading study at room temperature using base $\mathbf{2}$

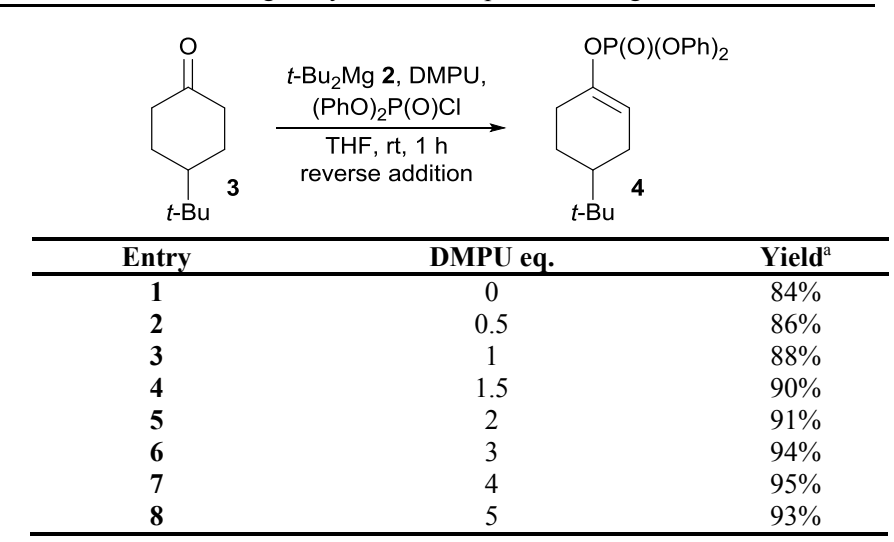

Reaction conditions: 4-tert-butylcyclohexanone $3(1 \mathrm{mmol})$, base $2(0.5$ $\mathrm{mmol})$, diphenylphosphoryl chloride $(1 \mathrm{mmol})$, THF $(11 \mathrm{~mL})$, reverse addition. ${ }^{a}$ Average isolated yield over two runs. 
Entries 2-7, Table 2, where, starting from $86 \%$ yield with 0.5 eq. of DMPU (Entry 2, Table 2), an excellent 95\% isolated yield of enol phosphate 4 was obtained when 4 eq. of the additive was employed (Entry 7, Table 2). In contrast to these accessible, room temperature conditions, use of more conventional lithium amide bases in the formation of 4 generally involves the use of a slight excess (1.1-1.3 eq) of base at $-78{ }^{\circ} \mathrm{C} .{ }^{10}$ Increasing the amount of DMPU additive beyond 4 eq. did not result in further improvements (Entry 8, Table 2). Thus, with an optimal set of reaction conditions in hand, the efficacy of our developed carbon-centred magnesium base protocol was explored across a range of substrates.

\section{Substrate scope with $t$-Bu2 $\mathrm{Mg} 2$}

We first investigated the reactivity of 2 with various 4-substituted cyclohexanones, as presented in Table 3. The steric impact of the substituent at the 4-position of the cyclohexanone was explored initially with the relatively small methyl unit and the planar phenyl group, with the corresponding enol phosphates $\mathbf{5}$ and $\mathbf{6}$ being isolated in excellent $93 \%$ and $90 \%$ yields, respectively. When a substrate bearing a more hindered, all-carbon quaternary centre at the 4-position was employed, the corresponding enol phosphate 7 was still delivered in an excellent $90 \%$ yield. In relation to the presence of heteroatoms in the substrate, the bulky 4-(tert-butyldimethyl)silyloxy substituent was compatible with our developed conditions, with enol phosphate $\mathbf{8}$ delivered in a good $79 \%$ yield. The presence of the potentially coordinating dimethylamino unit also proved to be applicable, allowing isolation of the corresponding enol phosphate 9 in $74 \%$ yield. Having observed excellent reactivity across a range of 4-substituted cyclohexanones, we then extended the scope to include acyclic aryl methyl ketones, starting with the parent acetophenone. Surprisingly, in this case only a trace amount (4\%) of product 10 was isolated. Instead, a large number of side reactions were observed. Among the various by-products, the product resulting from addition reaction of the base with the electrophile, and the aldol product were detected.

Table 3 Substrate scope under optimised conditions using base 2
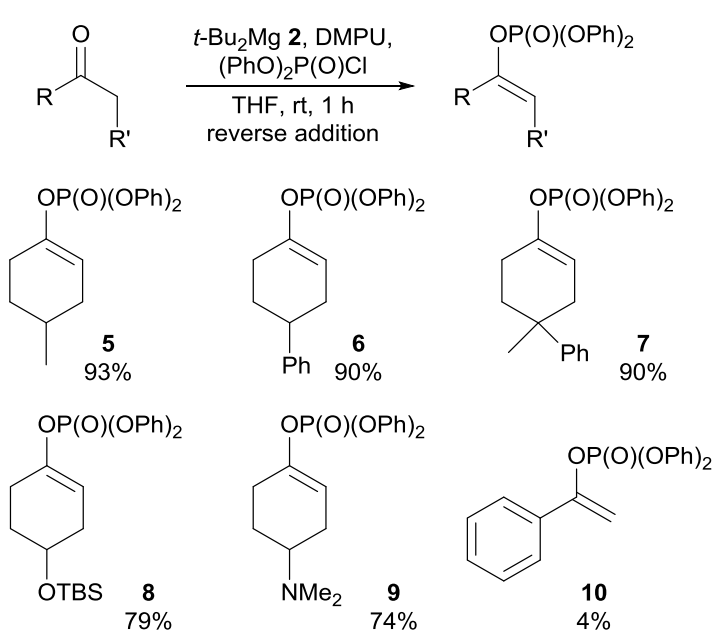

Reaction conditions: ketone ( $1 \mathrm{mmol})$, base 2 (0.5 mmol), DMPU (4 mmol), diphenylphosphoryl chloride $(1 \mathrm{mmol})$, THF $(11 \mathrm{~mL})$, reverse addition. Average isolated yield over two runs.
Further attempts to optimise the yield of product $\mathbf{1 0}$ using base $\mathbf{2}$ were unsuccessful. The high reactivity of this base was proposed to be responsible for the various side reactions; therefore, we turned our attention to dimesitylmagnesium $\mathbf{1}$, which we had already established as being less reactive than $\mathbf{2}$, and, in turn, a potentially more selective bases species.

\section{Optimisation of enol phosphate formation using $\mathrm{Mes}_{2} \mathrm{Mg} 1$}

As with our initial studies with di-tert-butylmagnesium 2, upon switching to dimesitylmagnesium 1, we first focused on optimising the enol phosphate formation with benchmark ketone 3. Bearing in mind the improvements observed when base $\mathbf{2}$ was employed at room temperature, we first examined this variable. As depicted in Scheme 4, the deprotonation reaction afforded an improved yield of $48 \%$ when base 1 was employed at room temperature, and, as before, quenching the reaction after $16 \mathrm{~h}$ instead of $1 \mathrm{~h}$ afforded the same yield of product.

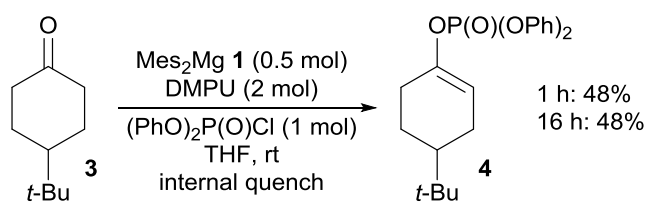

Scheme 4 Room temperature enol phosphate formation using base $\mathbf{1}$.

Although various quench protocols were again explored (see Supporting Information), the more classical internal quench protocol delivered the best results in this case with dimesitylmagnesium 1. We continued the optimisation by exploring the additive loading, and, as with base 2, a loading of 4 eq. of DMPU delivered the most favourable outcome (see Supporting Information), improving the yield to a moderate $57 \%$. We next examined the quantity of base used in the reaction. As shown in Scheme 5, employing only a relatively modest excess of base afforded an excellent $90 \%$ yield of enol phosphate product 4 . The electrophile stoichiometry was also explored (using 0.5 mol bas), but no appreciable overall improvement was observed (see Supporting Information).
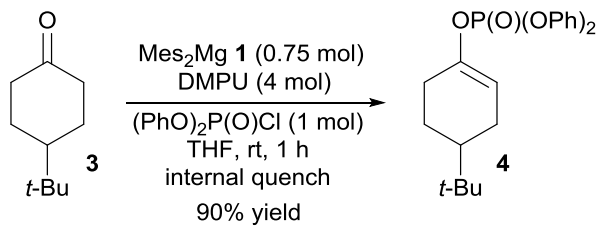

Scheme 5 Enol phosphate formation with a modest excess of base.

Pleased by this overall enhancement, we then returned to the aryl methyl ketones, to explore the reactivity of base 1 with a range of these more challenging substrates.

\section{Substrate scope with $\mathrm{Mes}_{2} \mathrm{Mg} 1$}

As shown in Table 4, and under the optimised conditions defined using base 1 in Scheme 5, the enol phosphate product 10, derived from acetophenone, was isolated in $77 \%$ yield; this constitutes a dramatic improvement from the trace amounts obtained using base 2 . We then explored various acetophenone derivatives to further expand the scope of this process (Table 4). The 4-bromo derivative of acetophenone afforded a good $75 \%$ yield of product 11 . Notably, the halogen group 
Table 4 Aryl methyl ketone substrate scope using base $\mathbf{1}$

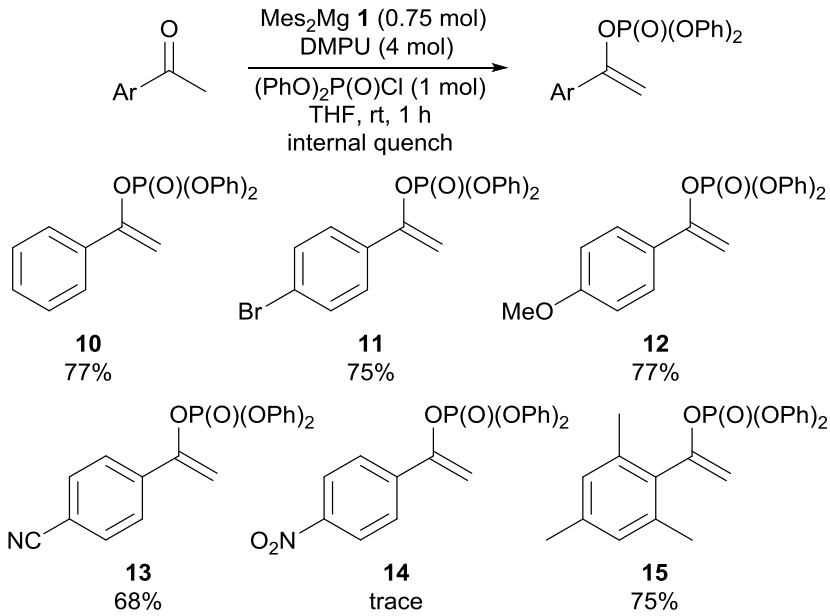

Average isolated yields over two runs are presented.

remained intact, as observed previously with the use of carbon-centred magnesium bases, ${ }^{6 \mathrm{a}, \mathrm{b}}$ and no products derived from $\mathrm{Br}-\mathrm{Mg}$ exchange were observed. Electron-rich enol phosphate 12, bearing a 4-methoxy group, was obtained in a good $77 \%$ yield. Interestingly, with the $4-$ cyano-substituted analogue, a $68 \%$ yield of product 13 was obtained, and, notably, no addition of the mesitylene group onto the cyano unit was observed under the room temperature reaction conditions.

Disappointingly, however, the presence of a nitro group in the substrate resulted in only trace quantities of product $14(3 \%)$ being obtained. We attribute this result to reaction of the nitro unit with the magnesium base.

Having investigated functional group compatibility, our attention then turned to a more sterically demanding substrate. The bulky mesityl methyl ketone afforded the corresponding enol phosphate product $\mathbf{1 5}$ in $75 \%$ yield. Overall and by way of contrasting with the accessible room temperature conditions developed here for the ready application of these more sensitive acyclic ketone substrates, the lithium amide basemediated formation of enol phosphates $\mathbf{1 0},{ }^{10 a, b, 11} \mathbf{1 2}$ and $\mathbf{1 3}^{12}$ all employ the considerably lower temperature of $-78^{\circ} \mathrm{C}$.

Finally, having explored the reactivity and substrate scope of our bases, we turned our attention to the regioselectivity exhibited under our developed reaction conditions. Previous studies have shown that carbon-centred bases $\mathbf{1}$ and $\mathbf{2}$ allowed access to kinetic enolate products ${ }^{6 \mathrm{~b}}$ but this selectivity was only studied at low temperatures. We therefore applied our optimised room temperature conditions to unsymmetrical ketone 16 (Scheme 6), and, pleasingly, both bases afforded the kinetic enol phosphate 17 in good yields (51-67\%) with no thermodynamic enol phosphate isomer detected. However, the increased bulk in the vicinity of the ketone would have appeared to have influenced the reactivity, as the overall efficiency of the

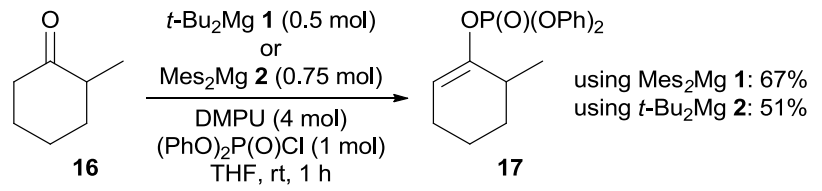

Scheme 6 Kinetic selectivity of the carbon-centred magnesium base system. transformation is slightly lower when compared to the yields for enol phosphates 4-9.

\section{Conclusions}

We have successfully developed an efficient and practically straightforward protocol for the synthesis of enol phosphates using carbon-centred magnesium bases. The process is characterised by short reaction times, ambient temperature conditions, and high reaction selectivities. The use of $t-\mathrm{Bu}_{2} \mathrm{Mg}, 2$, under a reverse addition protocol, delivered high reactivity in the case of 4-substituted cyclohexanone substrates. In contrast, $\mathrm{Mes}_{2} \mathrm{Mg}, \mathbf{1}$, a less reactive base, allowed the formation of enol phosphates from more sensitive ketones, bearing a variety of functional units. The stability of the products, and the facile process developed herein using carbon-centred bases $\mathbf{1}$ and 2, enables the enol phosphate products to be utilised as more readily accessible substrates for future synthetic challenges, which we will report on in due course.

\section{Acknowledgements}

We would like to thank the EPSRC and GlaxoSmithKline for financial support, and the EPSRC Mass Spectrometry Service, University of Wales, Swansea for analyses.

\section{Notes and references}

${ }^{a}$ Department of Pure and Applied Chemistry, WestCHEM, University of Strathclyde, 295 Cathedral Street, Glasgow, G1 1XL, UK, Tel: +44 1415482959 mail: w.kerr@strath.ac.uk

${ }^{b}$ GlaxoSmithKline, Medicines Research Centre, Gunnels Wood Road, Stevenage, Hertfordshire, SG1 2NY, UK

Electronic Supplementary Information (ESI) available: [details of any supplementary information available should be included here]. See DOI: $10.1039 / \mathrm{c} 000000 \mathrm{x} /$

1. (a) L. Sernissi, M. Petrovic, D. Scarpi, A. Guarna, A. Trabocchi, F. Bianchini, and E. G. Occhiato, Chem. Eur. J., 2014, 20, 11187; (b) D. Scarpi, L. Bartali, A. Casini, and E. G. Occhiato, Eur. J. Org. Chem., 2013, 2013, 1306; (c) N. Moinizadeh, R. Klemme, M. Kansy, R. Zimmer, and H.-U. Reissig, Synthesis, 2013, 45, 2752; (d) X. Jusseau, P. Retailleau, L. Chabaud, and C. Guillou, J. Org. Chem., 2013, 78, 2289; (e) S. Lebrun, A. Couture, E. Deniau, and P. Grandclaudona, Synthesis, 2012, 44, 1410; (f) M. Ebine, H. Fuwa, and M. Sasaki, Chem. Eur. J., 2011, 17, 13754; (g) C. Grison, N. Barthes, C. Finance, and R. E. Duval, Bioorg. Chem., 2010, 38, 218; (h) H. Fuwa, Bull. Chem. Soc. Jpn., 2010, 83, 1401; (i) Y. Nishino, M. Kobayashi, T. Shinno, K. Izumi, H. Yonezawa, Y. Masui, and M. Takahira, Org. Proc. Res. Dev., 2003, 7, 846; (j) R. J. Barney, R. M. Richardson, and D. F. Wiemer, J. Org. Chem., 2011, 76, 2875; (k) A. J. Wiemer, D. F. Wiemer, and R.J. Hohl, Clin. Pharmacol. Ther., 2011, 90, 805 .

2. (a) E. Krawczyk, G. Mielniczak, K. Owsianik, and J. Luczak, Tetrahedron: Asymmetry, 2012, 23, 1480; (b) P. H. Lee, D. Kang, S. Choi, and S. Kim, Org. Lett., 2011, 13, 3470; (c) F. M. Piller, T. Bresser, M. K. R. Fischer, and P. Knochel, J. Org. Chem., 2010, 75, 4365; (d) R. Knorr, E. C. Rossmann, and M. Knittl, Synthesis, 2010, 2124. 
3. (a) M. Cieslikiewicz, A. Bouet, S. Jugé, M. Toffano, J. Bayardon, C. West, K. Lewinski, and I. Gillaizeau, Eur. J. Org. Chem., 2012, 1101; (b) B.-J. Li, D.-G. Yu, C.-L. Sun, and Z.-J. Shi, Chem. Eur. J., 2011, 17, 1728; (c) H. Fuwa, Synlett, 2011, 6; (d) J. D. Sellars and P. G. Steel, Chem. Soc. Rev., 2011, 40, 5170.

4. (a) X.-Y. Zhu, J.-R. Chen, L.-Q. Lu, and W.-J Xiao, Tetrahedron, 2012, 68, 6032; (b) R.-J. Song, Y.-Y. Liu, J.-C. Wu, Y.-X. Xie, G.-B. Deng, X.-H. Yang, Y. Liu, and J.-H. Li, Synthesis, 2012, 44, 1119; (c) B. C. Chary, S. Kim, D. Shin, and P. H. Lee, Chem. Commun., 2011, 47, 7851; (d) N. Barthes and C. Grison, Bioorg. Chem., 2012, 40, 48; (e) P. H. Lee, S. Kim, A. Park, B. C. Chary, and S. Kim, Angew. Chem. Int. Ed., 2010, 49, 6806; (f) R. E. BarrientosAstigarraga, P. Castelani, C. Y. Sumida, J. Zukerman-Schpector, and J. V. Comasseto, Tetrahedron, 2002, 58, 1051; ( $g$ ) F. W. Lichtenthaler, Chem. Rev., 1961, 61, 607.

5. For examples where enol phosphates react with strong lithium amide bases to give vinyl anions, which then undergo $O$ - to $C$-phosphate transfer, see: (a) G. B. Hammond, T. Calogeropoulou, and D. F. Wiemer, Tetrahedron Lett., 1986, 27, 4265; (b) T. Calogeropoulou, G. B. Hammond, and D. F. Wiemer, J. Org. Chem., 1987, 52, 4185.

6. (a) W. J. Kerr, A. J. B. Watson, and D. Hayes, Org. Biomol. Chem., 2008, 6, 1238; (b) W. J. Kerr, A. J. B. Watson, and D. Hayes, Chem. Commun., 2007, 5049; (c) W. J. Kerr, A. J. B. Watson, and D. Hayes, Synlett, 2008, 1386.

7. The synthesis of enol phosphates from ketones has been the subject of a single report, where hindered Grignard reagents, as opposed to dialkylmagnesium species, were employed against a limited scope of ketone substrates: see, J. A. Miller, Tetrahedron Lett., 2002, 43, 7111.

8. B. E. Love and E. G. Jones, J. Org. Chem., 1999, 64, 3755.

9. (a) W. Clegg, F. J. Craig, K. W. Henderson, A. R. Kennedy, R. E. Mulvey, P. A. O’Neil, and D. Reed, Inorg. Chem., 1997, 36, 6238; (b) X. Sun and D. B. Collum, J. Am. Chem. Soc., 2000, 122, 2459; (c) K. W. Henderson, W. J. Kerr, and J. H. Moir, Tetrahedron, 2002, 58, 4573.

10. (a) K. Takai, K. Oshima, and H. Nozaki, Tetrahedron Lett., 1980, 21, 2531; (b) K. Takai, M. Sato, K. Oshima, and H. Nozaki, Bull. Chem. Soc. Jpn., 1984, 57, 108; (c) D. Gauthier, S. Beckendorf, T. M. Gøgsig, A. T. Lindhardt, and T. Skrydstrup, J. Org. Chem., 2009, 74, 3536.

11. (a) A. L. Hansen, J.-P. Ebran, M. Ahlquist, P.-O. Norrby, and T. Skrydstrup, Angew. Chem. Int. Ed., 2006, 45, 3349.

12. A. L. Hansen, J.-P. Ebran, T. M. Gøgsig, and T. Skrydstrup, Chem. Commun., 2006, 4137. 


\title{
Electronic Supplementary Information
}

\section{Efficient Methods for Enol Phosphate Synthesis Using Carbon-centred Magnesium}

\section{Bases}

\author{
William J. Kerr, ${ }^{* a}$ David M. Lindsay, ${ }^{a}$ Vipulkumar K. Patel, ${ }^{b}$ and Muralikrishnan Rajamanickam ${ }^{a}$ \\ ${ }^{a}$ Department of Pure and Applied Chemistry, WestCHEM, University of Strathclyde, 295 Cathedral Street, \\ Glasgow, G1 1XL, UK. \\ ${ }^{\mathrm{b}}$ GlaxoSmithKline, Medicines Research Centre, Gunnels Wood Road, Stevenage, Hertfordshire, SG1 2NY, UK
}

\section{Contents}

\begin{tabular}{lr} 
I. General Synthetic Methods & 2 \\
\hline
\end{tabular}

$\begin{array}{ll}\text { II. Experimental procedures } & 3\end{array}$

1. Experimental procedure: Scheme $2 \quad 3$

1A. Synthesis of Base 1

1B. Synthesis of Base 2

2. Experimental procedure: Table 1

2A. Typical reaction procedure with $\mathrm{LiCl}$ as additive 3

2B. Typical reaction procedure with DMPU as additive 3

3. Experimental procedure: Scheme $3 \quad 5$

3A. Specific procedure for the co-addition protocol 5

3B. Specific procedure for the reverse addition protocol $\quad 5$

4. Experimental procedure: Table 2

4A. Typical reaction procedure at room temperature using the reverse addition protocol 5

5. Experimental procedure: Table $3 \quad 6$

5A. Typical reaction procedure for the substrate scope using base $2 \quad 6$

6. Experimental procedure: Scheme $4 \quad 10$

6A. Specific reaction procedure at room temperature $\quad 10$

7. Additional experiments: Determining the optimised quench protocol with $\mathrm{Mes}_{2} \mathrm{Mg} \mathbf{1} 10$

$\begin{array}{ll}\text { 7A. Reverse addition } & 10\end{array}$

7B. Co-addition $\quad 10$

8. Additional experiments: Defining the optimised additive loading 11

8A. Typical reaction procedure $\quad 11$

9. Experimental procedure: Scheme 5 11

10. Additional experiments: Increasing the electrophile loading with the use of base $\mathbf{1} 12$

10A. Typical experimental procedure for the electrophile loading study $\quad 12$

11. Experimental procedure: Table $4 \quad 12$

11A. Typical procedure for the substrate scope using base $\mathbf{1}$

12. Experimental procedure: Scheme 6

12A. Experimental procedure for the formation of enol phosphate 16 using base $1 \quad 15$

$\begin{array}{ll}\text { III. NMR spectra }\left({ }^{1} \mathrm{H},{ }^{13} \mathrm{C},{ }^{31} \mathrm{P}\right) & 15\end{array}$

$\begin{array}{lr}\text { IV. References } & 43\end{array}$ 


\section{General Synthetic Methods}

All reagents were obtained from commercial suppliers (Aldrich, Lancaster, Alfa-Aesar, or Acros) and used without further purification, unless otherwise stated. Purification was carried out according to standard laboratory methods. ${ }^{1}$

- Tetrahydrofuran and 1,4-dioxane were dried by heating to reflux over sodium wire, using benzophenone ketyl as an indicator, and then distilled under nitrogen.

- DMPU and diphenylphosphoryl chloride were distilled over $\mathrm{CaH}_{2}$ under high vacuum and were stored over 4 Å molecular sieves under argon.

- Organometallic reagents were standardised using salicylaldehyde phenylhydrazone. ${ }^{2}$

- 4-tert-Butylcyclohexanone, 4-phenylcyclohexanone, 4-methyl-4-phenylcyclohexanone, 3 4'bromoacetophenone, 4'-methoxyacetophenone, 4-acetylbenzonitrile, mesitylethanone, and 4'nitroacetophenone were purified by recrystallization from hexane and were dried by storing under vacuum (0.005 mbar) for $16 \mathrm{~h}$.

- 4-Methylcyclohexanone, 4-((tert-butyldimethylsilyl)oxy)cyclohexanone,

4(dimethylamino)cyclohexanone, ${ }^{5}$ acetophenone, and 2-methylcyclohexanone were dried by distillation over $\mathrm{CaCl}_{2}$ and were stored under argon over $4 \AA$ molecular sieves.

Thin layer chromatography was carried out using Camlab silica plates, coated with fluorescent indicator $\mathrm{UV}_{254}$, and analysed using a Mineralight UVGL-25 lamp.

Flash column chromatography was carried out using Prolabo silica gel (230-400 mesh).

IR spectra were recorded on a SHIMADZU IRAFFINITY-1 spectrophotometer.

${ }^{1} \mathrm{H},{ }^{13} \mathrm{C}$, and ${ }^{31} \mathrm{P}$ spectra were recorded on a Bruker DPX 400 spectrometer at $400 \mathrm{MHz}, 100 \mathrm{MHz}$, and $162 \mathrm{MHz}$, respectively. Chemical shifts are reported in ppm. Coupling constants are reported in $\mathrm{Hz}$ and refer to ${ }^{3} J_{\mathrm{H}-\mathrm{H}}$ interactions, unless otherwise specified. 


\section{Experimental procedures}

\section{Experimental procedure: Scheme 2}

\section{A. Synthesis of dimesitylmagnesium 1}

A Schlenk flask was flame-dried under vacuum $(0.005$ mbar) and filled with argon. The flask was then evacuated and refilled with argon, this cycle repeated one further time, then the flask was allowed to cool to room temperature before addition of magnesium turnings $(1.9 \mathrm{~g}, 80 \mathrm{mmol})$. THF $(80 \mathrm{~mL})$ was added followed by a dropwise addition of $\operatorname{MesBr}(15.9 \mathrm{~g}, 12.24 \mathrm{~mL}, 80 \mathrm{mmol})$. A cold finger was quickly swapped with a suba seal and the Schlenk flask was heated slowly to $40{ }^{\circ} \mathrm{C}$ over $1 \mathrm{~h}$. After $5 \mathrm{~min}$, a reflux of the THF was observed due to the Grignard reaction initiating. After $30 \mathrm{~min}$, the end of the reflux was observed and the mixture was stirred at $40^{\circ} \mathrm{C}$ for a further $90 \mathrm{~min}$ before being allowed to cool to room temperature. The solution of $\mathrm{MesMgBr}$ was standardised with salicylalhdehyde phenylhydrazone. ${ }^{2}$ 1,4-Dioxane (1.05 eq., $105 \mathrm{mmol}, 9.25 \mathrm{~g}, 8.95 \mathrm{~mL}$ ) was then added dropwise to the mixture with stirring. The reaction mixture (now a yellow solution with a fine white precipitate) was then left to settle for $72 \mathrm{~h}$. After this time, the precipitate had settled to a thick white layer at the bottom of the Schlenk tube, allowing removal of the yellow $\mathrm{Mes}_{2} \mathrm{Mg}$ solution via cannula, to a previously flame-dried pear-shaped flask. Care was taken to avoid withdrawing any of the precipitate. The $\mathrm{Mes}_{2} \mathrm{Mg}$ solution was standardised before use, using salicylaldehyde phenylhydrazone as the indicator. ${ }^{2}$ The molarity of the $\mathrm{Mes}_{2} \mathrm{Mg}$ solution was typically $0.5 \mathrm{M}\left(100 \%\right.$ conversion of $\mathrm{MesMgBr}$ to $\mathrm{Mes}_{2} \mathrm{Mg}$, yield typically $\sim 90 \mathrm{~mL}, \sim$ $90 \%)$.

\section{B. Synthesis of bis(tert-butyl)magnesium 2}

To a solution of $t$-BuMgBr (1 M solution in THF, $100 \mathrm{~mL}, 100 \mathrm{mmol})$ charged to a flame-dried Schlenk tube under argon at rt was slowly added 1,4-dioxane (1.05 eq., $105 \mathrm{mmol}, 9.25 \mathrm{~g}, 8.95 \mathrm{~mL}$ ) over $5 \mathrm{~min}$. The mixture was stirred vigorously for $3 \mathrm{~h}$ before discontinuation of the stirring. The mixture (now a dark solution with a fine white precipitate) was then left to settle for $72 \mathrm{~h}$. After this time, the precipitate had settled to a thick white layer at the bottom of the Schlenk tube, allowing removal of the yellow $t$ - $\mathrm{Bu}_{2} \mathrm{Mg}$ solution via cannula to a previously flame-dried pear-shaped flask. Care was taken to avoid withdrawing any of the precipitate. $\mathrm{The}^{t}-\mathrm{Bu}_{2} \mathrm{Mg}$ solution was standardised before use using salicylaldehyde phenylhydrazone as indicator. ${ }^{2}$ The molarity of the ${ }^{t} \mathrm{Bu}_{2} \mathrm{Mg}$ solution was typically $0.5 \mathrm{M}\left(100 \%\right.$ conversion of $t$ - $\mathrm{BuMgBr}$ to $t-\mathrm{Bu}_{2} \mathrm{Mg}$, yield typically $\sim 90 \mathrm{~mL}, \sim$ $90 \%)$.

\section{Experimental procedure: Table 1}

\section{A. Typical reaction procedure with $\mathrm{LiCl}$ as additive}

A Schlenk flask was charged with $\mathrm{LiCl}$ (2 eq., $2 \mathrm{mmol}, 85 \mathrm{mg})$ and flame-dried under high vacuum (0.005 mbar), taking care not to melt the $\mathrm{LiCl}$, and then filled with argon. The flask was then evacuated and refilled with argon, this cycle repeated one further time, then the flask was allowed to cool to room temperature. A solution of carbon-centred base $(0.5 \mathrm{M}$ solution in THF, 0.5 eq., $0.5 \mathrm{mmol}, 1 \mathrm{~mL})$ and THF $(9 \mathrm{~mL})$ were added to the flask, cooled to $0{ }^{\circ} \mathrm{C}$ and stirred for an additional $5 \mathrm{~min}$ before addition of diphenylphosphoryl chloride ( $1 \mathrm{mmol}, 0.21$ $\mathrm{mL}$ ). The mixture was then stirred for $5 \mathrm{~min}$ before addition of the ketone $\mathbf{3}$ ( $1 \mathrm{mmol}, 154 \mathrm{mg})$ as a solution in THF ( $2 \mathrm{~mL}$ ) over $1 \mathrm{~h}$ via syringe pump, followed by stirring at $0{ }^{\circ} \mathrm{C}$ for the stated time. The reaction was quenched with a saturated solution of $\mathrm{NaHCO}_{3}(10 \mathrm{~mL})$ and allowed to warm to room temperature. The aqueous phase was extracted with $\mathrm{Et}_{2} \mathrm{O}(50,25,25 \mathrm{~mL})$ and the extracts combined. Removal of the solvent in vacuo gave an oil, which was purified by flash column chromatography on silica gel using 0-30\% $\mathrm{Et}_{2} \mathrm{O}$ in petroleum ether $\left(40-60{ }^{\circ} \mathrm{C}\right)$ to give the desired product 4 as a colourless oil.

\section{B. Typical reaction procedure with DMPU as additive}

A solution of base $(0.5 \mathrm{M}$ solution in THF, 0.5 eq., $0.5 \mathrm{mmol}, 1 \mathrm{~mL})$ was added to THF $(9 \mathrm{~mL})$ in a flame-dried Schlenk flask under argon. The mixture was cooled to $0{ }^{\circ} \mathrm{C}$ and stirred for an additional 5 min before addition of diphenylphosphoryl chloride (1 mmol, $0.21 \mathrm{~mL})$ and DMPU $(2 \mathrm{mmol}, 0.24 \mathrm{~mL})$, and stirred for a further $5 \mathrm{~min}$. The ketone 3 ( $1 \mathrm{mmol}, 154 \mathrm{mg})$, as a solution in THF $(2 \mathrm{~mL})$, was added over $1 \mathrm{~h}$ via syringe pump followed by 
stirring at $0{ }^{\circ} \mathrm{C}$ for the stated time. The reaction mixture was quenched with a saturated solution of $\mathrm{NaHCO}_{3}(5$ $\mathrm{mL})$ and allowed to warm to room temperature. The aqueous phase was extracted with $\mathrm{Et}_{2} \mathrm{O}(25,10,10 \mathrm{~mL})$ and the extracts combined. Removal of the solvent in vacuo gave an oil, which was purified by flash column chromatography on silica gel using $0-30 \% \mathrm{Et}_{2} \mathrm{O}$ in petroleum ether $\left(40-60{ }^{\circ} \mathrm{C}\right)$ to give the desired product 4 as a colourless oil.

For the entries in Table 1, each reaction was run twice under identical conditions, and the average yield is presented in the Table.

Following typical Procedure 2A or 2B, data are presented as: (a) $\mathrm{Mg}$ base, (b) reaction temperature, (c) additive, (d) amount of additive, (e) amount of $\mathrm{P}(\mathrm{O})(\mathrm{OPh})_{2} \mathrm{Cl}$, (f) ketone, (g) amount of ketone, (h) reaction time, (i) yield of run 1 , and $(\mathrm{j})$ yield of run 2 .

Table 1, Entry 1: General Procedure 2A: (a) $\mathrm{Mes}_{2} \mathrm{Mg}(0.5 \mathrm{mmol}, 1 \mathrm{~mL})$, (b) $0{ }^{\circ} \mathrm{C}$, (c) LiCl, (d) $84 \mathrm{mg}, 2 \mathrm{mmol}$, (e) $0.21 \mathrm{~mL}, 1 \mathrm{mmol}$, (f) 4-tert-butylcyclohexanone, (g) $154 \mathrm{mg}, 1 \mathrm{mmol}$, (h) $16 \mathrm{~h}$, (i) $108 \mathrm{mg}, 28 \%$, and (j) 112 mg, 29\%.

Table 1, Entry 2: General Procedure 2A: (a) $\mathrm{Mes}_{2} \mathrm{Mg}(0.5 \mathrm{mmol}, 1 \mathrm{~mL})$, (b) $0{ }^{\circ} \mathrm{C}$, (c) LiCl, (d) $84 \mathrm{mg}, 2 \mathrm{mmol}$, (e) $0.21 \mathrm{~mL}, 1 \mathrm{mmol}$, (f) 4-tert-butylcyclohexanone, (g) $154 \mathrm{mg}, 1 \mathrm{mmol}$, (h) $8 \mathrm{~h}$, (i) $120 \mathrm{mg}, 31 \%$, and (j) 119 mg, $31 \%$.

Table 1, Entry 3: General Procedure 2A: (a) $\mathrm{Mes}_{2} \mathrm{Mg}(0.5 \mathrm{mmol}, 1 \mathrm{~mL})$, (b) $0{ }^{\circ} \mathrm{C}$, (c) $\mathrm{LiCl}$, (d) $84 \mathrm{mg}, 2 \mathrm{mmol}$, (e) $0.21 \mathrm{~mL}, 1 \mathrm{mmol}$, (f) 4-tert-butylcyclohexanone, (g) $154 \mathrm{mg}, 1 \mathrm{mmol}$, (h) $1 \mathrm{~h}$, (i) $100 \mathrm{mg}, 26 \%$, and (j) 104 $\mathrm{mg}, 27 \%$.

Table 1, Entry 4: General Procedure 2B: (a) Mes $2 \mathrm{Mg}(0.5 \mathrm{mmol}, 1 \mathrm{~mL})$, (b) $0{ }^{\circ} \mathrm{C}$, (c) DMPU, (d) $0.24 \mathrm{~mL}, 2$ mmol, (e) $0.21 \mathrm{~mL}, 1 \mathrm{mmol}$, (f) 4-tert-butylcyclohexanone, (g) $154 \mathrm{mg}, 1 \mathrm{mmol}$, (h) $1 \mathrm{~h}$, (i) $153 \mathrm{mg}, 40 \%$, and (j) $150 \mathrm{mg}, 39 \%$.

Table 1, Entry 5: General Procedure 2A: (a) $t$-Bu $2 \mathrm{Mg}(0.5 \mathrm{mmol}, 1 \mathrm{~mL})$, (b) $0{ }^{\circ} \mathrm{C}$, (c) $\mathrm{LiCl}$, (d) $84 \mathrm{mg}, 2 \mathrm{mmol}$, (e) $0.21 \mathrm{~mL}, 1 \mathrm{mmol}$, (f) 4-tert-butylcyclohexanone, (g) $154 \mathrm{mg}, 1 \mathrm{mmol}$, (h) $1 \mathrm{~h}$, (i) $262 \mathrm{mg}, 68 \%$, and (j) 263 $\mathrm{mg}, 68 \%$.

Table 1, Entry 6: General Procedure 2B: (a) $t$-Bu $2 \mathrm{Mg}(0.5 \mathrm{mmol}, 1 \mathrm{~mL})$, (b) $0{ }^{\circ} \mathrm{C}$, (c) DMPU, (d) $0.24 \mathrm{~mL}, 2$ mmol, (e) $0.21 \mathrm{~mL}, 1 \mathrm{mmol}$, (f) 4-tert-butylcyclohexanone, (g) $154 \mathrm{mg}, 1 \mathrm{mmol}$, (h) $1 \mathrm{~h}$, (i) $290 \mathrm{mg}$, $75 \%$, and (j) $289 \mathrm{mg}, 75 \%$.

\section{Diphenyl 4-(tert-butyl)cyclohex-1-en-1-yl phosphate $4:^{6}$}

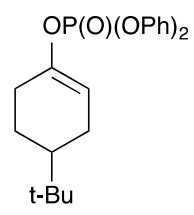

$v_{\max }: 1690,1191,963 \mathrm{~cm}^{-1}$

${ }^{1} \mathrm{H}$ NMR (400 MHz, $\left.\mathrm{CDCl}_{3}\right): \delta$ 7.39-7.32 (m, 4H, ArH), 7.27-7.17 (m, 6H, ArH), 5.58-5.53 (m, 1H, C=CH), 2.36-2.18 (m, $\left.2 \mathrm{H}, \mathrm{CH}_{2}\right), 2.16-2.05\left(\mathrm{~m}, 1 \mathrm{H}, \mathrm{CH}_{2}\right), 1.94-1.80\left(\mathrm{~m}, 2 \mathrm{H}, \mathrm{CH}_{2}\right), 1.39-1.22\left(\mathrm{~m}, 2 \mathrm{H}, \mathrm{CH}_{2}\right), 0.89(\mathrm{~s}, 9 \mathrm{H}$, $\left.\mathrm{C}\left(\mathrm{CH}_{3}\right)_{3}\right)$.

${ }^{13} \mathrm{C} \mathrm{NMR}\left(100 \mathrm{MHz}, \mathrm{CDCl}_{3}\right): \delta 151.0,148.1,130.1,125.7,120.5,112.2,43.6,32.4,29.0,27.6,25.3,24.8$.

${ }^{31} \mathrm{P}$ NMR $\left(162 \mathrm{~Hz}, \mathrm{CDCl}_{3}\right): \delta-17.46$. 


\section{Experimental procedure: Scheme 3}

\section{A. Specific procedure for the co-addition protocol}

A solution of base $2(0.5 \mathrm{M}$ solution in THF, 0.5 eq., $0.5 \mathrm{mmol}, 1 \mathrm{~mL})$ was added to THF $(9 \mathrm{~mL})$ in a flamedried Schlenk flask under argon. The mixture was cooled to $0{ }^{\circ} \mathrm{C}$ and stirred for an additional 5 minutes before addition of DMPU ( $2 \mathrm{mmol}, 0.24 \mathrm{~mL})$ and stirred for a further $5 \mathrm{~min}$. The ketone $3(1 \mathrm{mmol}, 154 \mathrm{mg})$ and diphenylphosphoryl chloride $(1 \mathrm{mmol}, 0.21 \mathrm{~mL})$ and THF $(2 \mathrm{~mL})$ were added to a previously flame-dried pear shaped flask under argon. This mixture was added to the Schlenk flask over $1 \mathrm{~h}$ via syringe pump, followed by stirring at $0{ }^{\circ} \mathrm{C}$ for $1 \mathrm{~h}$. The reaction mixture was quenched with a saturated solution of $\mathrm{NaHCO}_{3}(5 \mathrm{~mL})$ and allowed to warm to room temperature. The aqueous phase was extracted with $\mathrm{Et}_{2} \mathrm{O}(25,10,10 \mathrm{~mL})$ and the extracts combined. Removal of the solvent in vacuo gave an oil, which was purified by flash column chromatography on silica gel using $0-30 \% \mathrm{Et}_{2} \mathrm{O}$ in petroleum ether $\left(40-60{ }^{\circ} \mathrm{C}\right)$ to give the desired product 4 as a colourless oil (317 $\mathrm{mg}, 82 \%$ yield).

\section{B. Specific procedure for the reverse addition protocol}

A Schlenk flask was flame-dried under vacuum (0.005 mbar), purged three times with argon, and allowed to cool to room temperature before addition of the ketone $3(1 \mathrm{mmol}, 154 \mathrm{mg})$, diphenylphosphoryl chloride ( $1 \mathrm{mmol}, 0.21 \mathrm{~mL})$, DMPU $(2 \mathrm{mmol}, 0.24 \mathrm{~mL})$, and THF $(11 \mathrm{~mL})$. The mixture was cooled to $0{ }^{\circ} \mathrm{C}$ and stirred for $5 \mathrm{~min}$ before dropwise addition of base $2(0.5 \mathrm{M}$ solution in THF, 0.5 eq., $0.5 \mathrm{mmol}, 1 \mathrm{~mL})$ over $5 \mathrm{~min}$. After $1 \mathrm{~h}$ the reaction was quenched with a saturated solution of $\mathrm{NaHCO}_{3}(5 \mathrm{~mL})$ and allowed to warm to room temperature. The aqueous phase was extracted with $\mathrm{Et}_{2} \mathrm{O}(25,10,10 \mathrm{~mL})$. Removal of the solvent in vacuo gave an oil, which was purified by flash column chromatography on silica gel using 0-30 $\% \mathrm{Et}_{2} \mathrm{O}$ in petroleum ether $\left(40-60{ }^{\circ} \mathrm{C}\right)$ to give the desired product 4 as a colourless oil $(310 \mathrm{mg}, 80 \%$ yield $)$.

\section{Experimental procedure: Table 2}

\section{A. Typical reaction procedure at room temperature using the reverse addition protocol}

A Schlenk flask was flame-dried under vacuum (0.005 mbar), purged three times with argon, and allowed to cool to room temperature before addition of the ketone $3(1 \mathrm{mmol}, 154 \mathrm{mg})$, diphenylphosphoryl chloride (1 mmol, $0.21 \mathrm{~mL}$ ), DMPU (as stated in Table 2), and THF $(11 \mathrm{~mL})$. The mixture was stirred for $5 \mathrm{~min}$ before dropwise addition of base $2(0.5 \mathrm{M}$ solution in THF, 0.5 eq., $0.5 \mathrm{mmol}, 1 \mathrm{~mL})$ over $5 \mathrm{~min}$. After $1 \mathrm{~h}$ the reaction was quenched with a saturated solution of $\mathrm{NaHCO}_{3}(5 \mathrm{~mL})$. The aqueous phase was extracted with $\mathrm{Et}_{2} \mathrm{O}(25,10$, $10 \mathrm{~mL}$ ) and the extracts combined. Removal of the solvent in vacuo gave an oil, which was purified by flash column chromatography on silica gel using 0-30\% $\mathrm{Et}_{2} \mathrm{O}$ in petroleum ether $\left(40-60{ }^{\circ} \mathrm{C}\right)$ to give the desired product as a colourless oil.

Following typical Procedure 4A, data are presented as: (a) Mg base, (b) reaction temperature, (c) additive, (d) amount of additive, (e) amount of $\mathrm{P}(\mathrm{O})(\mathrm{OPh})_{2} \mathrm{Cl}$, (f) ketone, (g) amount of ketone, (h) reaction time, (i) yield of run 1 , and $(\mathrm{j})$ yield of run 2 .

For the entries in Table 2, each reaction was run twice under identical conditions, and the average yield is presented in the Table.

Table 2, Entry 1: General Procedure 4A: (a) $t$-Bu $\mathrm{Bu}_{2} \mathrm{Mg}(0.5 \mathrm{mmol}, 1 \mathrm{~mL})$, (b) rt, (c) n/a, (d) n/a, (e) $0.21 \mathrm{~mL}, 1$ mmol, (f) 4-tert-butylcyclohexanone, (g) $154 \mathrm{mg}, 1 \mathrm{mmol}$, (h) $1 \mathrm{~h}$, (i) $324 \mathrm{mg}, 84 \%$, and (j) $325 \mathrm{mg}, 84 \%$. 
Table 2, Entry 2: General Procedure 4A: (a) $t$-Bu $\mathrm{Bu}_{2} \mathrm{Mg}(0.5 \mathrm{mmol}, 1 \mathrm{~mL})$, (b) rt, (c) DMPU, (d) $0.06 \mathrm{~mL}, 0.5$ mmol, (e) $0.21 \mathrm{~mL}, 1 \mathrm{mmol}$, (f) 4-tert-butylcyclohexanone, (g) $154 \mathrm{mg}, 1 \mathrm{mmol}$, (h) $1 \mathrm{~h}$, (i) $332 \mathrm{mg}, 86 \%$, and (j) $334 \mathrm{mg}, 86 \%$.

Table 2, Entry 3: General Procedure 4A: (a) $t$-Bu $\mathrm{Bu}_{2}(0.5 \mathrm{mmol}, 1 \mathrm{~mL})$, (b) rt, (c) DMPU, (d) $0.12 \mathrm{~mL}, 1$ mmol, (e) $0.21 \mathrm{~mL}, 1 \mathrm{mmol}$, (f) 4-tert-butylcyclohexanone, (g) $154 \mathrm{mg}, 1 \mathrm{mmol}$, (h) $1 \mathrm{~h}$, (i) $336 \mathrm{mg}, 87 \%$, and (j) $340 \mathrm{mg}, 88 \%$.

Table 2, Entry 4: General Procedure 4A: (a) $t$-Bu $\mathrm{Bu}_{2} \mathrm{Mg}(0.5 \mathrm{mmol}, 1 \mathrm{~mL})$, (b) rt, (c) DMPU, (d) $0.18 \mathrm{~mL}, 1.5$ mmol, (e) $0.21 \mathrm{~mL}, 1 \mathrm{mmol}$, (f) 4-tert-butylcyclohexanone, (g) $154 \mathrm{mg}, 1 \mathrm{mmol}$, (h) $1 \mathrm{~h}$, (i) $348 \mathrm{mg}$, $90 \%$, and (j) $349 \mathrm{mg}, 90 \%$.

Table 2, Entry 5: General Procedure 4A: (a) $t$-Bu $\mathrm{Bu}_{2} \mathrm{Mg}(0.5 \mathrm{mmol}, 1 \mathrm{~mL})$, (b) rt, (c) DMPU, (d) $0.24 \mathrm{~mL}, 2$ mmol, (e) $0.21 \mathrm{~mL}, 1 \mathrm{mmol}$, (f) 4-tert-butylcyclohexanone, (g) $154 \mathrm{mg}, 1 \mathrm{mmol}$, (h) $1 \mathrm{~h}$, (i) $352 \mathrm{mg}$, $91 \%$, and (j) $349 \mathrm{mg}, 90 \%$.

Table 2, Entry 6: General Procedure 4A: (a) $t$-Bu글 $(0.5 \mathrm{mmol}, 1 \mathrm{~mL})$, (b) rt, (c) DMPU, (d) $0.36 \mathrm{~mL}, 3$ mmol, (e) $0.21 \mathrm{~mL}, 1 \mathrm{mmol}$, (f) 4-tert-butylcyclohexanone, (g) $154 \mathrm{mg}, 1 \mathrm{mmol}$, (h) $1 \mathrm{~h}$, (i) $359 \mathrm{mg}, 93 \%$, and (j) $371 \mathrm{mg}, 96 \%$.

Table 2, Entry 7: General Procedure 4A: (a) $t$-Bu $\mathrm{Bu}_{2} \mathrm{Mg}(0.5 \mathrm{mmol}, 1 \mathrm{~mL})$, (b) rt, (c) DMPU, (d) $0.48 \mathrm{~mL}, 4$ mmol, (e) $0.21 \mathrm{~mL}, 1 \mathrm{mmol}$, (f) 4-tert-butylcyclohexanone, (g) $154 \mathrm{mg}, 1 \mathrm{mmol}$, (h) $1 \mathrm{~h}$, (i) $369 \mathrm{mg}, 95 \%$, and (j) $368 \mathrm{mg}, 95 \%$.

Table 2, Entry 8: General Procedure 4A: (a) $t$-Bu $\mathrm{Bu}_{2} \mathrm{Mg}(0.5 \mathrm{mmol}, 1 \mathrm{~mL})$, (b) rt, (c) DMPU, (d) $0.60 \mathrm{~mL}, 5$ mmol, (e) $0.21 \mathrm{~mL}, 1 \mathrm{mmol}$, (f) 4-tert-butylcyclohexanone, (g) $154 \mathrm{mg}, 1 \mathrm{mmol}$, (h) $1 \mathrm{~h}$, (i) $359 \mathrm{mg}$, $93 \%$, and (j) $355 \mathrm{mg}, 92 \%$.

\section{Experimental procedure: Table 3}

\section{A. Typical reaction procedure for the substrate scope using base 2}

A Schlenk flask was flame-dried under vacuum (0.005 mbar), purged three times with argon, and allowed to cool to room temperature before addition of the ketone, diphenylphosphoryl chloride ( $1 \mathrm{mmol}, 0.21 \mathrm{~mL}), \mathrm{DMPU}$ $(4 \mathrm{mmol}, 0.48 \mathrm{~mL})$ and THF $(11 \mathrm{~mL})$. The mixture was stirred for $5 \mathrm{~min}$ before dropwise addition of base $1(0.5$ M solution in THF, 0.5 eq., $0.5 \mathrm{mmol}, 1 \mathrm{~mL}$ ) over $5 \mathrm{~min}$. After $1 \mathrm{~h}$ the reaction was quenched with a saturated solution of $\mathrm{NaHCO}_{3}(5 \mathrm{~mL})$. The aqueous phase was extracted with $\mathrm{Et}_{2} \mathrm{O}(25,10,10 \mathrm{~mL})$ and the extracts combined. Removal of the solvent in vacuo gave an oil which was purified by column chromatography on silica gel using 0-30\% $\% \mathrm{Et}_{2} \mathrm{O}$ in petroleum ether $\left(40-60{ }^{\circ} \mathrm{C}\right)$ to give the desired product.

Following typical Procedure 5A, data are presented as: (a) Mg base, (b) reaction temperature, (c) additive, (d) amount of additive, (e) amount of $\mathrm{P}(\mathrm{O})(\mathrm{OPh})_{2} \mathrm{Cl}$, (f) ketone, (g) amount of ketone, (h) reaction time, (i) yield of run $1,(\mathrm{j})$ yield of run 2 , and $(\mathrm{k})$ appearance.

For the entries in Table 3, each reaction was run twice under identical conditions, and the average yield is presented in the Table.

Table 3, compound 5: General Procedure 5A: (a) $t-\mathrm{Bu}_{2} \mathrm{Mg}(0.5 \mathrm{mmol}, 1 \mathrm{~mL})$, (b) rt, (c) DMPU, (d) $0.48 \mathrm{~mL}, 4$ mmol, (e) $0.21 \mathrm{~mL}, 1 \mathrm{mmol}$, (f) 4-methylcyclohexanone, (g) $112 \mathrm{mg}, 1 \mathrm{mmol}$, (h) $1 \mathrm{~h}$, (i) $316 \mathrm{mg}, 92 \%$, (j) 323 $\mathrm{mg}, 94 \%$, and $(\mathrm{k})$ colourless oil. 


\section{Diphenyl 4-methylcyclohex-1-enyl phosphate 5:}

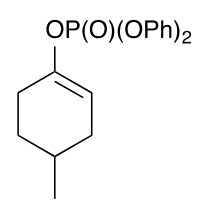

$v_{\max }: 1589,1487,1296,1186,1114,945 \mathrm{~cm}^{-1}$.

${ }^{1} \mathrm{H}$ NMR (400 MHz, $\left.\mathrm{CDCl}_{3}\right): \delta$ 7.39-7.33 (m, 4H, ArH), 7.26-7.18 (m, 6H, ArH), 5.58-5.50 (m, 1H, C=CH), 2.36-2.20 (m, $\left.3 \mathrm{H}, \mathrm{CH}_{2}\right), 1.80-1.62\left(\mathrm{~m}, 3 \mathrm{H}, \mathrm{CH}_{2}, \mathrm{CH}\right), 1.43-1.31\left(\mathrm{~m}, 1 \mathrm{H}, \mathrm{CH}_{2}\right), 0.97\left(\mathrm{~d}, J=6.4 \mathrm{~Hz}, 3 \mathrm{H}, \mathrm{CH}_{3}\right)$.

${ }^{13} \mathrm{C} \mathrm{NMR}\left(100 \mathrm{MHz}, \mathrm{CDCl}_{3}\right): \delta 150.9,148.0,130.1,125.7,120.4,111.6,32.2,31.0,27.9,27.7,21.3$.

${ }^{31} \mathrm{P}$ NMR $\left(162 \mathrm{MHz}, \mathrm{CDCl}_{3}\right): \delta-17.46$.

HRMS (ESI) Calculated for $\mathrm{C}_{19} \mathrm{H}_{22} \mathrm{O}_{4} \mathrm{P}[\mathrm{M}+\mathrm{H}]^{+}:$345.1250; found: 345.1244 .

Table 3, compound 6: General Procedure 5A: (a) $t$ - $\mathrm{Bu}_{2} \mathrm{Mg}(0.5 \mathrm{mmol}, 1 \mathrm{~mL})$, (b) rt, (c) DMPU, (d) $0.48 \mathrm{~mL}, 4$ mmol, (e) $0.21 \mathrm{~mL}, 1 \mathrm{mmol}$, (f) 4-phenylcyclohexanone, (g) $174 \mathrm{mg}, 1 \mathrm{mmol}$, (h) $1 \mathrm{~h}$, (i) $365 \mathrm{mg}, 90 \%$, (j) 366 $\mathrm{mg}, 90 \%$, and (k) white solid.

\section{Diphenyl (1,2,3,6-tetrahydro-[1,1'-biphenyl]-4-yl) phosphate 6:}<smiles>OCCOc1ccccc1</smiles>

$v_{\max }: 1688,1587,1489,1282,1188,1105,939 \mathrm{~cm}^{-1}$.

${ }^{1} \mathrm{H}$ NMR (400 MHz, $\mathrm{CDCl}_{3}$ ): $\delta$ 7.41-7.34 (m, 4H, ArH), 7.32-7.25 (m, 6H, ArH), 7.24-7.19 (m, 5H, ArH), 5.70$5.65(\mathrm{~m}, 1 \mathrm{H}, \mathrm{C}=\mathrm{CH}), 2.87-2.77(\mathrm{~m}, 1 \mathrm{H}, \mathrm{CH}), 2.54-2.21\left(\mathrm{~m}, 4 \mathrm{H}, \mathrm{CH}_{2}\right), 2.07-1.98\left(\mathrm{~m}, 1 \mathrm{H}, \mathrm{CH}_{2}\right), 1.97-1.85(\mathrm{~m}, 1 \mathrm{H}$, $\left.\mathrm{CH}_{2}\right)$.

${ }^{13} \mathrm{C}$ NMR (100 MHz, $\left.\mathrm{CDCl}_{3}\right): \delta 150.7,147.8,145.5,129.9,128.6,126.9,126.4,125.5,120.2,111.6,39.2,31.6$, 29.7, 28.1.

${ }^{31} \mathrm{P}$ NMR $\left(162 \mathrm{MHz}, \mathrm{CDCl}_{3}\right): \delta-17.40$.

HRMS (ESI) Calculated for $\mathrm{C}_{24} \mathrm{H}_{24} \mathrm{O}_{4} \mathrm{P}[\mathrm{M}+\mathrm{H}]^{+}$: 407.1407; found: 407.1408. 
Table 3, compound 7: General Procedure 5A: (a) $t$ - $\mathrm{Bu}_{2} \mathrm{Mg}(0.5 \mathrm{mmol}, 1 \mathrm{~mL})$, (b) rt, (c) DMPU, (d) $0.48 \mathrm{~mL}, 4$ mmol, (e) $0.21 \mathrm{~mL}, 1 \mathrm{mmol}$, (f) 4-methyl-4-phenylcyclohexanone, (g) $188 \mathrm{mg}, 1 \mathrm{mmol}$, (h) $1 \mathrm{~h}$, (i) $378 \mathrm{mg}$, $90 \%$, (j) $374 \mathrm{mg}, 89 \%$, and (k) colourless oil.

\section{Diphenyl 1-methyl-1,2,3,6-tetrahydro-[1,1'-biphenyl]-4-yl phosphate 7:}

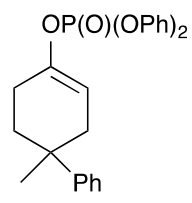

$v_{\max }: 1687,1589,1487,1294,1186,1114,943 \mathrm{~cm}^{-1}$.

${ }^{1} \mathrm{H}$ NMR (400 MHz, $\left.\mathrm{CDCl}_{3}\right): \delta$ 7.39-7.29 (m, 8H, ArH), 7.24-7.17 (m, 7H, ArH), 5,7-5.65 (m, 1H, C=CH), 2.67$2.56\left(\mathrm{~m}, 1 \mathrm{H}, \mathrm{CH}_{2}\right), 2.32-2.2\left(\mathrm{~m}, 2 \mathrm{H}, \mathrm{CH}_{2}\right), 2.11-1.97\left(\mathrm{~m}, 2 \mathrm{H}, \mathrm{CH}_{2}\right), 1.91-1.82\left(\mathrm{~m}, 1 \mathrm{H}, \mathrm{CH}_{2}\right), 1.31\left(\mathrm{~s}, 3 \mathrm{H}, \mathrm{CH}_{3}\right)$.

${ }^{13} \mathrm{C} \mathrm{NMR}\left(100 \mathrm{MHz}, \mathrm{CDCl}_{3}\right): \delta 150.9,48.1,147.6,130.1,128.6,126.2,125.9,125.7,120.4,110.8,36.5,36.0$, $35.2,28.8,25.9$.

${ }^{31} \mathrm{P}$ NMR $\left(162 \mathrm{MHz}, \mathrm{CDCl}_{3}\right): \delta-17.64$

HRMS (ESI) Calculated for $\mathrm{C}_{25} \mathrm{H}_{26} \mathrm{O}_{4} \mathrm{P}[\mathrm{M}+\mathrm{H}]^{+}: 421.1563$; found: 421.1554.

Table 3, compound 8: General Procedure 5A: (a) $t$-Bu $\mathrm{Bu}_{2} \mathrm{Mg}(0.5 \mathrm{mmol}, 1 \mathrm{~mL})$, (b) rt, (c) DMPU, (d) $0.48 \mathrm{~mL}, 4$ mmol, (e) $0.21 \mathrm{~mL}, 1 \mathrm{mmol}$, (f) 4-((tert-butyldimethylsilyl)oxy)cyclohexanone, (g) $228 \mathrm{mg}, 1 \mathrm{mmol}$, (h) $1 \mathrm{~h}$, (i) $359 \mathrm{mg}, 78 \%$, (j) $368 \mathrm{mg}, 80 \%$, and (k) colourless oil.

\section{Diphenyl 4-((tert-butyldimethylsilyl)oxy)cyclohex-1-enyl phosphate 8:}<smiles>O=COc1ccccc1</smiles>

$v_{\max }: 1589,1489,1296,1251,1188,1101,943 \mathrm{~cm}^{-1}$.

${ }^{1} \mathrm{H}$ NMR (400 MHz, $\left.\mathrm{CDCl}_{3}\right): \delta$ 7.39-7.32 (m, 4H, ArH), 7.26-7.18 (m, 6H, ArH), 5.47-5.42 (m, 1H, C=CH), 3.96-3.87 (m, 1H, CH), 2.40-2.24 (m, 3H, $\left.\mathrm{CH}_{2}\right), 2.14-2.03\left(\mathrm{~m}, 1 \mathrm{H}, \mathrm{CH}_{2}\right), 1.83-1.70\left(\mathrm{~m}, 2 \mathrm{H}, \mathrm{CH}_{2}\right), 0.88(\mathrm{~s}, 9 \mathrm{H}$, $\left.\mathrm{C}\left(\mathrm{CH}_{3}\right)_{3}\right), 0.06\left(\mathrm{~s}, 6 \mathrm{H}, \mathrm{CH}_{3}\right)$.

${ }^{13} \mathrm{C} \mathrm{NMR}\left(100 \mathrm{MHz}, \mathrm{CDCl}_{3}\right): \delta 150.9,147.4,130.1,125.8,120.5,109.4,66.5,33.3,31.5,26.2,26.0,18.5,-4.4$.

${ }^{31} \mathrm{P}$ NMR (162 MHz, $\left.\mathrm{CDCl}_{3}\right): \delta-17.62$. 
HRMS (ESI) Calculated for $\mathrm{C}_{24} \mathrm{H}_{34} \mathrm{O}_{5} \mathrm{PSi}[\mathrm{M}+\mathrm{H}]^{+}$: 461.1908 ; found: 461.1896.

Table 3, compound 9: General Procedure 5A: (a) $t$ - $\mathrm{Bu}_{2} \mathrm{Mg}(0.5 \mathrm{mmol}, 1 \mathrm{~mL})$, (b) rt, (c) DMPU, (d) $0.48 \mathrm{~mL}, 4$ mmol, (e) $0.21 \mathrm{~mL}, 1 \mathrm{mmol}$, (f) 4-(dimethylamino)cyclohexanone, (g) $141 \mathrm{mg}, 1 \mathrm{mmol}$, (h) $1 \mathrm{~h}$, (i) $280 \mathrm{mg}, 75 \%$, (j) $272 \mathrm{mg}, 73 \%$, and $(\mathrm{k})$ yellow oil.

\section{Diphenyl 4-(dimethylamino)cyclohex-1-enyl phosphate 9:}<smiles>CN(C)C1CC=C(Oc2ccccc2)CC1</smiles>

$v_{\max }: 1591,1487,1222,1155,1083,887 \mathrm{~cm}^{-1}$

${ }^{1} \mathrm{H}$ NMR (400 MHz, $\left.\mathrm{CDCl}_{3}\right): \delta$ 7.39-7.32 (m, 4H ArH), 7.26-7.18 (m, 6H ArH), 5.54-5.49 (m, 1H C=CH), 2.61$2.46\left(\mathrm{~m}, 2 \mathrm{H}, \mathrm{CH}_{2}, \mathrm{CH}\right), 2.33\left(\mathrm{~s}, 6 \mathrm{H}, \mathrm{N}-\mathrm{CH}_{3}\right), 2.30-2.21\left(\mathrm{~m}, 2 \mathrm{H}, \mathrm{CH}_{2}\right), 2.17-2.06\left(\mathrm{~m}, 1 \mathrm{H}, \mathrm{CH}_{2}\right), 2.04-1.96(\mathrm{~m}, 1 \mathrm{H}$, $\left.\mathrm{CH}_{2}\right), 1.65-1.53\left(\mathrm{~m}, 1 \mathrm{H}, \mathrm{CH}_{2}\right)$.

${ }^{13} \mathrm{C}$ NMR $\left(100 \mathrm{MHz}, \mathrm{CDCl}_{3}\right): \delta 150.9,147.6,130.2,129.6,125.8,120.4,59.7,41.9,27.8,25.7,25.3$.

${ }^{31} \mathrm{P}$ NMR (162 MHz, $\left.\mathrm{CDCl}_{3}\right): \delta-17.53$.

HRMS (ESI) Calculated for $\mathrm{C}_{20} \mathrm{H}_{25} \mathrm{NO}_{4} \mathrm{P}[\mathrm{M}+\mathrm{H}]^{+}: 374.1516$; found: 374.1516 .

Table 3, compound 10: General Procedure 5A: (a) $t$-Bu $\mathrm{Bu}_{2} \mathrm{Mg}(0.5 \mathrm{mmol}, 1 \mathrm{~mL})$, (b) rt, (c) DMPU, (d) $0.48 \mathrm{ml}, 4$ mmol, (e) $0.21 \mathrm{ml}, 1 \mathrm{mmol}$, (f) acetophenone, (g) $120 \mathrm{mg}, 1 \mathrm{mmol}$, (h) $1 \mathrm{~h}$, (i) $7 \mathrm{mg}, 2 \%$, (j) $21 \mathrm{mg}, 6 \%$, and (k) yellow oil.

\section{Diphenyl 1-phenylethen-1-yl phosphate 10: ${ }^{7}$}

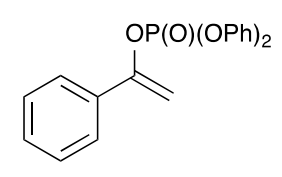

$v_{\max }: 1683,1589,1487,1184,1010,947 \mathrm{~cm}^{-1}$.

${ }^{1} \mathrm{H}$ NMR (400 MHz, $\left.\mathrm{CDCl}_{3}\right): \delta$ 7.39-7.29 (m, 10H, ArH), 7.25-7.16 (m, 5H, ArH), 5.42-5.39 (m, 1H, C=CH), 5.36-5.34 (m, 1H, C=CH).

${ }^{13} \mathrm{C}$ NMR (100 MHz, $\left.\mathrm{CDCl}_{3}\right): \delta$ 152.6, 150.8, 130.2, 130.1, 129.6, 128.8, 125.9, 125.6, 120.5, 98.7. 
HRMS (ESI) Calculated for $\mathrm{C}_{20} \mathrm{H}_{17} \mathrm{NaO}_{4} \mathrm{P}[\mathrm{M}+\mathrm{Na}]^{+}: 375.0757$; found: 375.0757 .

\section{Experimental procedure: Scheme 4}

\section{A. Specific reaction procedure at room temperature}

A solution of base 1 ( $0.5 \mathrm{M}$ solution in THF, 0.5 eq., $0.5 \mathrm{mmol}, 1 \mathrm{~mL})$ was added to THF $(9 \mathrm{~mL})$ in a flamedried Schlenk flask. Diphenylphosphoryl chloride $(1 \mathrm{mmol}, 0.21 \mathrm{~mL})$ and DMPU (2 mmol, $0.24 \mathrm{~mL})$ were added to the mixture and stirred for a further $5 \mathrm{~min}$. The ketone 3 (1 mmol, $154 \mathrm{mg})$, as a solution in THF (2 $\mathrm{mL}$ ), was added over $1 \mathrm{~h}$ via syringe pump followed by stirring at room temperature for the stated time. The mixture was quenched with a saturated solution of $\mathrm{NaHCO}_{3}(5 \mathrm{~mL})$ after the stated time. The aqueous phase was extracted with $\mathrm{Et}_{2} \mathrm{O}(25,10,10 \mathrm{~mL})$ and the extracts combined. Removal of the solvent in vacuo gave an oil, which was purified by flash column chromatography on silica gel using 0-30\% $\mathrm{Et}_{2} \mathrm{O}$ in petroleum ether (40$60{ }^{\circ} \mathrm{C}$ ) to give the desired product 4 as a colourless oil.

Reaction time $1 \mathrm{~h}: 185 \mathrm{mg}, 48 \%$ yield.

Reaction time $16 \mathrm{~h}: 185 \mathrm{mg}, 48 \%$ yield.

\section{Additional experiments: Determining the optimised quench protocol with $\mathrm{Mes} 2 \mathrm{Mg} 1$}

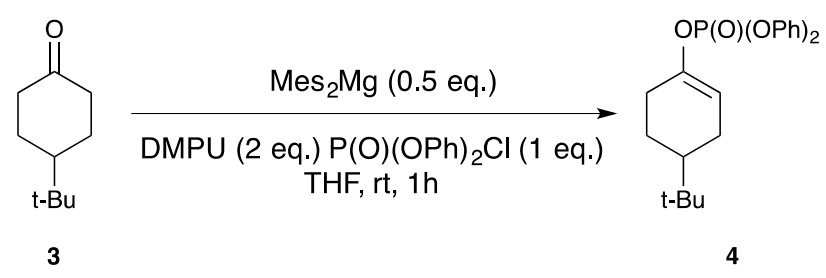

\section{A. Reverse addition:}

A Schlenk flask was flame-dried under vacuum (0.005 mbar) and filled with argon. The flask was then evacuated and refilled with argon, this cycle repeated one further time, then the flask was allowed to cool to room temperature, before addition of the ketone $3(1 \mathrm{mmol}, 154 \mathrm{mg})$, diphenylphosphoryl chloride $(1 \mathrm{mmol}$, $0.21 \mathrm{~mL})$, DMPU $(0.24 \mathrm{~mL}, 2 \mathrm{mmol})$, and THF $(11 \mathrm{~mL})$. The mixture was stirred for 5 min before dropwise addition of base 1 ( $0.5 \mathrm{M}$ solution in THF, 0.25 eq., $0.25 \mathrm{mmol}, 0.5 \mathrm{~mL}$ ) over $5 \mathrm{~min}$. After $1 \mathrm{~h}$, the reaction was quenched with a saturated solution of $\mathrm{NaHCO}_{3}(5 \mathrm{~mL})$. The aqueous phase was extracted with $\mathrm{Et}_{2} \mathrm{O}(25,10,10$ $\mathrm{mL}$ ) and the extracts combined. Removal of the solvent in vacuo gave an oil which was purified by column chromatography on silica gel using $0-30 \% \mathrm{Et}_{2} \mathrm{O}$ in petroleum ether $\left(40-60{ }^{\circ} \mathrm{C}\right)$ to give the desired product 4 as a colourless oil (120 mg, 31\% yield).

\section{B. Co-addition:}

A solution of base 1 ( $0.5 \mathrm{M}$ solution in THF, 0.5 eq., $0.5 \mathrm{mmol}, 1 \mathrm{~mL})$ was added to THF $(9 \mathrm{~mL})$ in a flamedried Schlenk flask under argon, followed by the addition of DMPU ( $2 \mathrm{mmol}, 0.24 \mathrm{~mL})$. The ketone 3 ( $1 \mathrm{mmol}$, $154 \mathrm{mg})$, diphenylphosphoryl chloride $(1 \mathrm{mmol}, 0.21 \mathrm{~mL})$ and THF $(2 \mathrm{~mL})$ were added to a flame-dried pear shaped flask under argon. This mixture was added into the Schlenk flask over $1 \mathrm{~h}$ via syringe pump, followed by stirring at $\mathrm{rt}$ for $1 \mathrm{~h}$. The reaction mixture was quenched with a saturated solution of $\mathrm{NaHCO}_{3}(5 \mathrm{~mL})$ and allowed to warm to room temperature. The aqueous phase was extracted with $\mathrm{Et}_{2} \mathrm{O}(25,10,10 \mathrm{~mL})$ and the extracts combined. Removal of the solvent in vacuo gave an oil, which was purified by flash column chromatography on silica gel using 0-30\% $\mathrm{Et}_{2} \mathrm{O}$ in petroleum ether $\left(40-60{ }^{\circ} \mathrm{C}\right)$ to give the desired product $4 \mathrm{a}$ colourless oil (185 mg, $48 \%$ yield). 


\section{Additional experiments: Defining the optimised additive loading}

\section{A. Typical reaction procedure}

A solution of base $1(0.5 \mathrm{M}$ solution in THF, 0.5 eq., $0.5 \mathrm{mmol}, 1 \mathrm{~mL})$ was added to THF $(9 \mathrm{~mL})$ in a flamedried Schlenk flask under argon. Diphenylphosphoryl chloride and DMPU were added to the mixture and stirred for a further $5 \mathrm{~min}$. The ketone $\mathbf{3}$, as a solution in THF $(2 \mathrm{~mL})$, was added over $1 \mathrm{~h}$ via syringe pump followed by stirring at room temperature for the stated time. The mixture was quenched with a saturated solution of $\mathrm{NaHCO}_{3}$ $(5 \mathrm{~mL})$ after the stated time. The aqueous phase was extracted with $\mathrm{Et}_{2} \mathrm{O}(25,10,10 \mathrm{~mL})$ and the extracts combined. Removal of the solvent in vacuo gave an oil which was purified by column chromatography on silica gel using 0-30\% $\mathrm{Et}_{2} \mathrm{O}$ in petroleum ether $\left(40-60{ }^{\circ} \mathrm{C}\right)$ to give the desired product 4 as a colourless oil.

Following typical Procedure 8A, data are presented as (a) Mg base, (b) reaction temperature, (c) additive, (d) amount of additive, (e) amount of $\mathrm{P}(\mathrm{O})(\mathrm{OPh})_{2} \mathrm{Cl}$, (f) ketone, $(\mathrm{g})$ amount of ketone, (h) reaction time, and (i) yield.

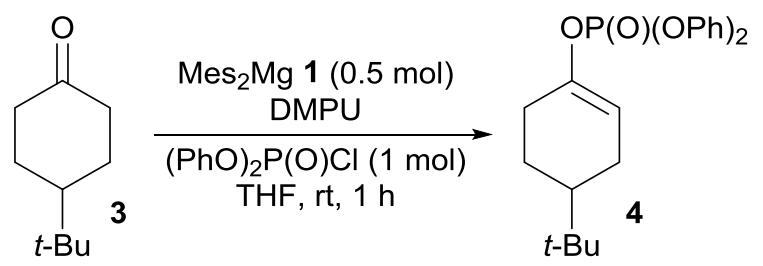

\begin{tabular}{ccc}
\hline Entry & DMPU (mmol) & Isolated Yield \\
\hline $\mathbf{1}$ & 1 & $36 \%$ \\
$\mathbf{2}$ & 4 & $57 \%$ \\
$\mathbf{3}$ & 6 & $45 \%$ \\
$\mathbf{4}$ & 8 & $41 \%$
\end{tabular}

Table S1 Varying the DMPU loading with the application of base 1

Table S1, Entry 1: General Procedure 8A: (a) $\operatorname{Mes}_{2} \mathrm{Mg}(0.5 \mathrm{mmol}, 1 \mathrm{~mL}$ ), (b) rt, (c) DMPU, (d) $0.12 \mathrm{~mL}, 1$ mmol, (e) $0.21 \mathrm{~mL}, 1 \mathrm{mmol}$, (f) 4-tert-butylcyclohexanone, (g) $154 \mathrm{mg}, 1 \mathrm{mmol}$, (h) $1 \mathrm{~h}$, and (i) $139 \mathrm{mg}, 36 \%$.

Table S1, Entry 2: General Procedure 8A: (a) $\operatorname{Mes}_{2} \mathrm{Mg}(0.5 \mathrm{mmol}, 1 \mathrm{~mL}$ ), (b) rt, (c) DMPU, (d) $0.48 \mathrm{~mL}, 4$ mmol, (e) $0.21 \mathrm{~mL}, 1 \mathrm{mmol}$, (f) 4-tert-butylcyclohexanone, (g) $154 \mathrm{mg}, 1 \mathrm{mmol}$, (h) $1 \mathrm{~h}$, and (i) $220 \mathrm{mg}, 57 \%$.

Table S1, Entry 3: General Procedure 8A: (a) $\operatorname{Mes}_{2} \mathrm{Mg}(0.5 \mathrm{mmol}, 1 \mathrm{~mL})$, (b) rt, (c) DMPU, (d) $0.72 \mathrm{~mL}, 6$ mmol, (e) $0.21 \mathrm{~mL}, 1 \mathrm{mmol}$, (f) 4-tert-butylcyclohexanone, (g) $154 \mathrm{mg}, 1 \mathrm{mmol}$, (h) $1 \mathrm{~h}$, (i) $174 \mathrm{mg}, 45 \%$.

Table S1, Entry 4: General Procedure 8A: (a) $\operatorname{Mes}_{2} \mathrm{Mg}(0.5 \mathrm{mmol}, 1 \mathrm{~mL}$ ), (b) rt, (c) DMPU, (d) $0.96 \mathrm{~mL}, 8$ mmol, (e) $0.21 \mathrm{~mL}, 1 \mathrm{mmol}$, (f) 4-tert-butylcyclohexanone, (g) $154 \mathrm{mg}, 1 \mathrm{mmol}$, (h) $1 \mathrm{~h}$, (i) $158 \mathrm{mg}, 41 \%$.

\section{Experimental procedure: Scheme 5}

A solution of base $(0.5 \mathrm{M}$ solution in THF, 0.75 eq., $0.75 \mathrm{mmol}, 1.5 \mathrm{~mL})$ was added to THF ( $9 \mathrm{~mL})$ in a flamedried Schlenk flask under argon. Diphenylphosphoryl chloride (1 mmol, $0.21 \mathrm{~mL})$ and DMPU (4 mmol, 0.48 $\mathrm{mL}$ ) were added to the mixture and stirred for a further $5 \mathrm{~min}$. The ketone 3 (1 mmol, $154 \mathrm{mg})$ as a solution in THF ( $2 \mathrm{~mL}$ ) was added over $1 \mathrm{~h}$ via syringe pump followed by stirring at room temperature for $1 \mathrm{~h}$. The mixture was quenched with a saturated solution of $\mathrm{NaHCO}_{3}(5 \mathrm{~mL})$. The aqueous phase was extracted with $\mathrm{Et}_{2} \mathrm{O}(25,10$, $10 \mathrm{~mL}$ ) and the extracts combined. Removal of the solvent in vacuo gave an oil which was purified by column chromatography on silica gel using $0-30 \% \mathrm{Et}_{2} \mathrm{O}$ in petroleum ether $\left(40-60{ }^{\circ} \mathrm{C}\right)$ to give the desired product 4 as a colourless oil (348 mg, 90\% yield). 


\section{Additional experiments: Increasing the electrophile loading with the use of base 1}

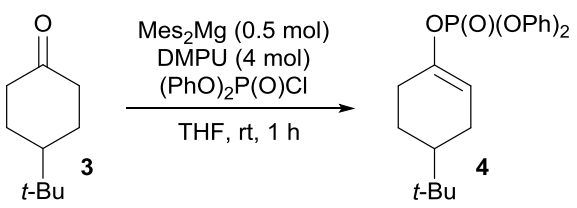

\begin{tabular}{ccc}
\hline Entry & Electrophile loading (mmol) & Isolated yield \\
\hline $\mathbf{1}$ & 1.5 & $74 \%$ \\
$\mathbf{2}$ & 2 & $69 \%$ \\
$\mathbf{3}$ & 4 & $69 \%$
\end{tabular}

Table S2 Varying the electrophile loading with the use of base 1

\section{A. Typical experimental procedure for the electrophile loading study}

A solution of base $\mathbf{1}$ and THF $(9 \mathrm{~mL})$ were added to a flame-dried Schlenk flask under argon. Diphenylphosphoryl chloride and DMPU were added to the mixture and stirred for a further $5 \mathrm{~min}$. The ketone $\mathbf{3}$ as a solution in THF $(2 \mathrm{~mL})$ was added over $1 \mathrm{~h}$ via syringe pump followed by stirring at room temperature for 1 h. The mixture was quenched with a saturated solution of $\mathrm{NaHCO}_{3}(5 \mathrm{~mL})$. The aqueous phase was extracted with $\mathrm{Et}_{2} \mathrm{O}(25,10,10 \mathrm{~mL})$ and the extracts combined. Removal of the solvent in vacuo gave an oil which was purified by column chromatography on silica gel using $0-30 \% \mathrm{Et}_{2} \mathrm{O}$ in petroleum ether $\left(40-60{ }^{\circ} \mathrm{C}\right)$ to give the desired product $\mathbf{4}$ as a colourless oil.

Following typical Procedure 10A, data are presented as: (a) Mg base, (b) reaction temperature, (c) additive, (d) amount of additive, (e) amount of $\mathrm{P}(\mathrm{O})(\mathrm{OPh})_{2} \mathrm{Cl}$, (f) ketone, (g) amount of ketone, (h) reaction time, and (i) yield.

Table S2, Entry 1: General Procedure 10A: (a) $\mathrm{Mes}_{2} \mathrm{Mg}(0.5 \mathrm{mmol}, 1 \mathrm{~mL})$, (b) rt, (c) DMPU, (d) $0.48 \mathrm{~mL}, 4$ mmol, (e) $0.31 \mathrm{~mL}, 1.5 \mathrm{mmol}$, (f) 4-tert-butylcyclohexanone, (g) $154 \mathrm{mg}, 1 \mathrm{mmol}$, (h) $1 \mathrm{~h}$, and (i) $286 \mathrm{mg}, 74 \%$.

Table S2, Entry 2: General Procedure 10A: (a) $\mathrm{Mes}_{2} \mathrm{Mg}(0.5 \mathrm{mmol}, 1 \mathrm{~mL})$, (b) rt, (c) DMPU, (d) $0.48 \mathrm{~mL}, 4$ mmol, (e) $0.42 \mathrm{~mL}, 2 \mathrm{mmol}$, (f) 4-tert-butylcyclohexanone, (g) $154 \mathrm{mg}, 1 \mathrm{mmol}$, (h) $1 \mathrm{~h}$, and (i) $266 \mathrm{mg}, 69 \%$.

Table S2, Entry 3: General Procedure 10A: (a) $\mathrm{Mes}_{2} \mathrm{Mg}(0.5 \mathrm{mmol}, 1 \mathrm{~mL})$, (b) rt, (c) DMPU, (d) $0.48 \mathrm{~mL}, 4$ mmol, (e) $0.84 \mathrm{~mL}, 4 \mathrm{mmol}$, (f) 4-tert-butylcyclohexanone, (g) $154 \mathrm{mg}, 1 \mathrm{mmol}$, (h) $1 \mathrm{~h}$, and (i) $267 \mathrm{mg}, 69 \%$.

\section{Experimental procedure: Table 4}

\section{A. Typical procedure for the aryl methyl ketone substrate scope using base 1}

A solution of base $(0.5 \mathrm{M}$ solution in THF, 0.75 eq., $0.75 \mathrm{mmol}, 1.5 \mathrm{~mL})$ was added to THF $(9 \mathrm{~mL})$ in a flamedried Schlenk flask under argon. Diphenylphosphoryl chloride $(1 \mathrm{mmol}, 0.21 \mathrm{~mL})$ and DMPU $(4 \mathrm{mmol}, 0.48$ $\mathrm{mL}$ ) were added to the mixture and stirred for a further $5 \mathrm{~min}$. The ketone substrate was added as a solution in THF ( $2 \mathrm{~mL}$ ) over $1 \mathrm{~h}$ via syringe pump followed by stirring at room temperature for $1 \mathrm{~h}$. The mixture was quenched with a saturated solution of $\mathrm{NaHCO}_{3}(5 \mathrm{~mL})$. The aqueous phase was extracted with $\mathrm{Et}_{2} \mathrm{O}(25,10,10$ $\mathrm{mL}$ ) and the extracts combined. Removal of the solvent in vacuo gave an oil which was purified by column chromatography on silica gel using 0-30\% $\mathrm{Et}_{2} \mathrm{O}$ in petroleum ether $\left(40-60{ }^{\circ} \mathrm{C}\right)$ to give the desired product. 
Following typical Procedure 11A, data are presented as: (a) Mg base, (b) reaction temperature, (c) additive, (d) amount of additive, (e) amount of $\mathrm{P}(\mathrm{O})(\mathrm{OPh})_{2} \mathrm{Cl}$, (f) ketone, (g) amount of ketone, (h) reaction time, (i) yield run $1,(\mathrm{j})$ yield run 2 , and $(\mathrm{k})$ appearance.

For the entries in Table 4, each reaction was run twice under identical conditions, and the average yield is presented in the Table.

Table 4, compound 10: General Procedure 11A: (a) $\mathrm{Mes}_{2} \mathrm{Mg}$ (0.75 mmol, $1.5 \mathrm{~mL}$ ), (b) rt, (c) DMPU, (d) 0.48 mL, 4 mmol, (e) $0.21 \mathrm{~mL}, 1 \mathrm{mmol}$, (f) acetophenone, (g) $120 \mathrm{mg}, 1 \mathrm{mmol}$, (h) $1 \mathrm{~h}$, (i) $271 \mathrm{mg}, 77 \%$, (j) $268 \mathrm{mg}$, $76 \%$, and $(\mathrm{k})$ colourless oil.

Table 4, compound 11: General Procedure 11A: (a) Mes ${ }_{2} \mathrm{Mg}$ (0.75 mmol, $1.5 \mathrm{~mL}$ ), (b) rt, (c) DMPU, (d) 0.48 mL, 4 mmol, (e) $0.21 \mathrm{~mL}, 1 \mathrm{mmol}$, (f) 4-bromoacetophenone, (g) $199 \mathrm{mg}, 1 \mathrm{mmol}$, (h) $1 \mathrm{~h}$, (i) $322 \mathrm{mg}, 75 \%$, (j) $323 \mathrm{mg}, 75 \%$, and $(\mathrm{k})$ colourless oil.

\section{Diphenyl 1-(4-bromophenyl)ethen-1-yl phosphate 11:}<smiles>C=C(O[OH+])OCc1ccc(Br)cc1</smiles>

$v_{\max }: 1587,1487,1184,1298,1265,1211,1006,954,941 \mathrm{~cm}^{-1}$.

${ }^{1} \mathrm{H}$ NMR (400 MHz, $\left.\mathrm{CDCl}_{3}\right): \delta$ 7.46-7.42 (m, 2H, ArH), 7.38-7.33 (m, 6H, ArH), 7.26-7.16 (m, 6H, ArH), 5.41$5.36\left(\mathrm{~m}, 2 \mathrm{H}, \mathrm{C}=\mathrm{CH}_{2}\right)$.

${ }^{13} \mathrm{C}$ NMR (100 MHz, $\left.\mathrm{CDCl}_{3}\right): \delta 151.8,150.8,131.9,130.2,130.6,127.1,126.6,123.9,120.5,99.3$.

${ }^{31} \mathrm{P}$ NMR $\left(162 \mathrm{MHz}, \mathrm{CDCl}_{3}\right): \delta-17.80$.

HRMS (ESI) Calculated for $\mathrm{C}_{20} \mathrm{H}_{17} \mathrm{BrO}_{4} \mathrm{P}[\mathrm{M}+\mathrm{H}]^{+}$: 431.0042/433.0022; found: 431.0035/433.0012.

Table 4, compound 12: General Procedure 11A: (a) Mes $2 \mathrm{Mg}(0.75 \mathrm{mmol}, 1.5 \mathrm{~mL})$, (b) rt, (c) DMPU, (d) 0.48 $\mathrm{mL}, 4 \mathrm{mmol}$, (e) $0.21 \mathrm{~mL}, 1 \mathrm{mmol}$, (f) 4-methoxyacetophenone, (g) $150 \mathrm{mg}, 1 \mathrm{mmol}$, (h) $1 \mathrm{~h}$, (i) $290 \mathrm{mg}, 76 \%$, (j) $294 \mathrm{mg}, 77 \%$, and (k) colourless oil.

\section{Diphenyl 1-(4-methoxyphenyl)ethen-1-yl phosphate 12: ${ }^{8}$}<smiles>C=C(OP)OCc1ccc(OC)cc1</smiles>

$v_{\max }: 1671,1595,1489,1257,1186,918 \mathrm{~cm}^{-1}$. 
${ }^{1} \mathrm{H}$ NMR (400 MHz, $\mathrm{CDCl}_{3}$ ): $\delta$ 7.47-7.40 (m, 2H, ArH), 7.38-7.32 (m, 4H, ArH), 7.28-7.17 (m, 6H, ArH), 6.87$6.81(\mathrm{~m}, 2 \mathrm{H}, \mathrm{ArH}), 5.28-5.21\left(\mathrm{~m}, 2 \mathrm{H}, \mathrm{C}=\mathrm{CH}_{2}\right), 3.82\left(\mathrm{~s}, 3 \mathrm{H}, \mathrm{CH}_{3}\right)$.

${ }^{13} \mathrm{C}$ NMR (100 MHz, $\left.\mathrm{CDCl}_{3}\right): 160.8,152.6,150.9,130.2,127.1,125.9,120.6,120.5,114.1,96.8,55.7$.

${ }^{31} \mathrm{P}$ NMR (162 MHz, $\left.\mathrm{CDCl}_{3}\right): \delta-17.75$.

HRMS (ESI) Calculated for $\mathrm{C}_{21} \mathrm{H}_{20} \mathrm{O}_{5} \mathrm{P}[\mathrm{M}+\mathrm{H}]^{+}: 383.1045$; found: 383.1043 .

Table 4, compound 13: General Procedure 11A: (a) $\mathrm{Mes}_{2} \mathrm{Mg}$ (0.75 mmol, $1.5 \mathrm{~mL}$ ), (b) rt, (c) DMPU, (d) 0.48 mL, 4 mmol, (e) $0.21 \mathrm{~mL}, 1 \mathrm{mmol}$, (f) 4-cyanoacetophenone, (g) $145 \mathrm{mg}, 1 \mathrm{mmol}$, (h) $1 \mathrm{~h}$, (i) $256 \mathrm{mg}, 68 \%$, (j) $257 \mathrm{mg}, 68 \%$, and $(\mathrm{k})$ colourless oil.

\section{Diphenyl 1-(4-cyanophenyl)ethen-1-yl phosphate 13: ${ }^{8}$}<smiles>C=C(OCCO)OCCOC</smiles>

$v_{\max }: 2227,1589,1487,1300,1182,1093,1008,958 \mathrm{~cm}^{-1}$.

${ }^{1} \mathrm{H}$ NMR (400 MHz, $\left.\mathrm{CDCl}_{3}\right): \delta$ 7.63-7.54 (m, 4H, ArH), 7.40-7.33 (m, 4H, ArH), 7.26-7.16 (m, 6H, ArH), 5.56$5.50\left(\mathrm{~m}, 2 \mathrm{H}, \mathrm{C}=\mathrm{CH}_{2}\right)$.

${ }^{13} \mathrm{C}$ NMR $\left(100 \mathrm{MHz}, \mathrm{CDCl}_{3}\right): \delta 151.0,150.7,138.12,132.6,130.30,126.2,126.1120 .43,118.7113 .1,101.9$.

${ }^{31} \mathrm{P}$ NMR $\left(162 \mathrm{MHz}, \mathrm{CDCl}_{3}\right): \delta-17.78$.

HRMS (ESI) Calculated for $\mathrm{C}_{21} \mathrm{H}_{17} \mathrm{NO}_{4} \mathrm{P}[\mathrm{M}+\mathrm{H}]^{+}: 378.0898$; found: 378.0888 .

Table 4, compound 14: General Procedure 11A: (a) $\operatorname{Mes}_{2} \mathrm{Mg}(0.75 \mathrm{mmol}, 1.5 \mathrm{ml})$, (b) rt, (c) DMPU, (d) $0.48 \mathrm{ml}$, $4 \mathrm{mmol}$, (e) $0.21 \mathrm{ml}, 1 \mathrm{mmol}$, (f) (4-nitrophenyl)ethanone, (g) $165 \mathrm{mg}, 1 \mathrm{mmol}$, (h) $1 \mathrm{~h}$, (i) $8 \mathrm{mg}, 2 \%$, (j) $15 \mathrm{mg}$, $4 \%$, and (k) red oil.

\section{Diphenyl 1-(4-nitrophenyl)ethen-1-yl phosphate 14:}<smiles>C=C(OCCOC)c1ccc([N+](=O)[O-])cc1</smiles>

$v_{\max }: 1591,1485,1456,1296,1265,1222,1184,1161,1128,1008,948 \mathrm{~cm}^{-1}$. 
${ }^{1} \mathrm{H}$ NMR (400 MHz, $\left.\mathrm{CDCl}_{3}\right): \delta$ 7.36-7.31 (m, 4H, ArH), 7.25-7.17 (m, 6H, ArH), 6.94-6.89 (m, 1H, C=CH$)$, 6.87-6.83 (m, 2H, ArH), 6.82-6.77 (m, 2H, $\mathrm{ArH}), 5.32\left(\mathrm{~s}, 1 \mathrm{H}, \mathrm{C}=\mathrm{CH}_{2}\right)$.

${ }^{13} \mathrm{C}$ NMR $\left(100 \mathrm{MHz}, \mathrm{CDCl}_{3}\right): \delta 156.2,150.9,146.3,135.4,130.1,129.9,125.8,120.8,120.6,115.6$.

${ }^{31} \mathrm{P}$ NMR (162 MHz, $\left.\mathrm{CDCl}_{3}\right): \delta-17.23$.

Table 4, compound 15: General Procedure 11A: (a) $\mathrm{Mes}_{2} \mathrm{Mg}(0.75 \mathrm{mmol}, 1.5 \mathrm{~mL})$, (b) rt, (c) DMPU, (d) 0.48 $\mathrm{mL}, 4 \mathrm{mmol}$, (e) $0.21 \mathrm{~mL}, 1 \mathrm{mmol}$, (f) mesitylethanone, (g) $162 \mathrm{mg}, 1 \mathrm{mmol}$, (h) $1 \mathrm{~h}$, (i) $296 \mathrm{mg}, 75 \%$, (j) 296 $\mathrm{mg}, 75 \%$, and $(\mathrm{k})$ yellow oil.

\section{Diphenyl 1-mesitylethen-1-yl phosphate 15:}<smiles>C=C(OCCO)Oc1c(C)cc(C)cc1C</smiles>

$v_{\max }: 1589,1487,1296,1213,1186,1161,1008,939 \mathrm{~cm}^{-1}$.

${ }^{1} \mathrm{H}$ NMR (400 MHz, $\mathrm{CDCl}_{3}$ ): $\delta$ 7.39-7.28 (m, 4H, ArH), 7.23-7.15 (m, 6H, ArH), 6.85 (s, 2H, ArH), 5.51-5.47

$\left(\mathrm{m}, 1 \mathrm{H}, \mathrm{C}=\mathrm{CH}_{2}\right), 4.81-4.78\left(\mathrm{~m}, 1 \mathrm{H}, \mathrm{C}=\mathrm{CH}_{2}\right), 2.31\left(\mathrm{~s}, 6 \mathrm{H}, \mathrm{CH}_{3}\right), 2.29\left(\mathrm{~s}, 3 \mathrm{H}, \mathrm{CH}_{3}\right)$.

${ }^{13} \mathrm{C} \mathrm{NMR}\left(100 \mathrm{MHz}, \mathrm{CDCl}_{3}\right): \delta 151.5,150.8,139.1,137.5,131.8,130.0,128.5,125.7,120.4,103.9,21.4,20.3$.

${ }^{31} \mathrm{P}$ NMR (162 MHz, $\left.\mathrm{CDCl}_{3}\right): \delta-18.34$.

HRMS (ESI) Calculated for $\mathrm{C}_{23} \mathrm{H}_{24} \mathrm{O}_{4} \mathrm{P}[\mathrm{M}+\mathrm{H}]^{+}:$395.1407; found: 395.1403 .

\section{Experimental procedure: Scheme 6}

\section{A. Experimental procedure for the formation of enol phosphate 16 using base 1}

A solution of base $1(0.5 \mathrm{M}$ solution in THF, 0.75 eq., $0.75 \mathrm{mmol}, 1.5 \mathrm{~mL})$ was added to THF $(9 \mathrm{~mL})$ in a flamedried Schlenk flask under argon. Diphenylphosphoryl chloride $(1 \mathrm{mmol}, 0.21 \mathrm{~mL})$ and DMPU $(4 \mathrm{mmol}, 0.48$ $\mathrm{mL}$ ) were added to the mixture and stirred for a further $5 \mathrm{~min}$. 2-Methylcyclohexanone (112 $\mathrm{mg}, 1 \mathrm{mmol})$ was added as a solution in THF $(2 \mathrm{~mL})$ over $1 \mathrm{~h}$ via syringe pump, followed by stirring at room temperature for $1 \mathrm{~h}$. The reaction mixture was quenched with a saturated solution of $\mathrm{NaHCO}_{3}(5 \mathrm{~mL})$. The aqueous phase was extracted with $\mathrm{Et}_{2} \mathrm{O}(25,10,10 \mathrm{~mL})$ and the extracts combined. Removal of the solvent in vacuo gave an oil, which was purified by flash column chromatography on silica gel using $0-30 \% \mathrm{Et}_{2} \mathrm{O}$ in petroleum ether (40$\left.60{ }^{\circ} \mathrm{C}\right)$ to give the desired product $16(230 \mathrm{mg}, 67 \%$ yield $)$ as a colourless oil.

\section{B. Experimental procedure for the formation of enol phosphate 16 using base 2}

A Schlenk flask was flame-dried under vacuum $(0.005 \mathrm{mbar})$ and filled with argon. The flask was then evacuated and refilled with argon, this cycle repeated one further time, then the flask was allowed to cool to room temperature, before addition of 2-methylcyclohexanone (112 mg, $1 \mathrm{mmol})$, diphenylphosphoryl chloride (1 mmol, $0.21 \mathrm{~mL})$, DMPU (4 mmol, $0.48 \mathrm{~mL})$, and THF $(11 \mathrm{~mL})$. The mixture was stirred for $5 \mathrm{~min}$ before 
dropwise addition of base $2(0.5 \mathrm{M}$ solution in THF, 0.5 eq., $0.5 \mathrm{mmol}, 1 \mathrm{~mL})$ over $5 \mathrm{~min}$. After $1 \mathrm{~h}$ the reaction was quenched with a saturated solution of $\mathrm{NaHCO}_{3}(5 \mathrm{~mL})$. The aqueous phase was extracted with $\mathrm{Et}_{2} \mathrm{O}(25,10$, $10 \mathrm{~mL}$ ) and the extracts combined. Removal of the solvent in vacuo gave an oil, which was purified by flash column chromatography on silica gel using 0-30\% $\mathrm{Et}_{2} \mathrm{O}$ in petroleum ether $\left(40-60{ }^{\circ} \mathrm{C}\right)$ to give the desired product (175 mg, 51\% yield) as a colourless oil.

\section{Diphenyl 6-methylcyclohex-1-en-1-yl phosphate 17: ${ }^{9}$}

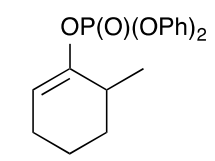

$v_{\max }: 1589,1487,1294,1186,1101,950 \mathrm{~cm}^{-1}$

${ }^{1} \mathrm{H}$ NMR (400 MHz, $\left.\mathrm{CDCl}_{3}\right): \delta$ 7.39-7.33 (m, 5H, ArH), 7.26-7.33 (m, 5H, ArH), 5.63-5.59 (m, 1H, C=CH), 2.45-2.37 (m, 1H), 2.12-2.06 (m, 2H), 1.87-1.80 (m, 1H), 1.67-1.58 (m, 1H), 1.56-1.48 (m, 1H), 1.47-1.37 (m, $1 \mathrm{H}), 1.04\left(\mathrm{~d}, J=7.0 \mathrm{~Hz}, 3 \mathrm{H}, \mathrm{CH}_{3}\right)$.

${ }^{13} \mathrm{C}$ NMR $\left(100 \mathrm{MHz}, \mathrm{CDCl}_{3}\right): \delta 152.1,150.9,130.1,125.7,120.5,111.7,32.4,31.5,24.5,19.7,18.4$.

${ }^{31} \mathrm{P}$ NMR (162 MHz, $\left.\mathrm{CDCl}_{3}\right): \delta-17.52$.

HRMS (ESI) Calculated for $\mathrm{C}_{19} \mathrm{H}_{22} \mathrm{O}_{4} \mathrm{P}[\mathrm{M}+\mathrm{H}]^{+}: 345.1250$; found: 345.1246 
III. NMR spectra $\left({ }^{1} \mathrm{H},{ }^{13} \mathrm{C},{ }^{31} \mathrm{P}\right)$<smiles>CC(C)(C)C1CC=C(OCOc2ccccc2)CC1</smiles>
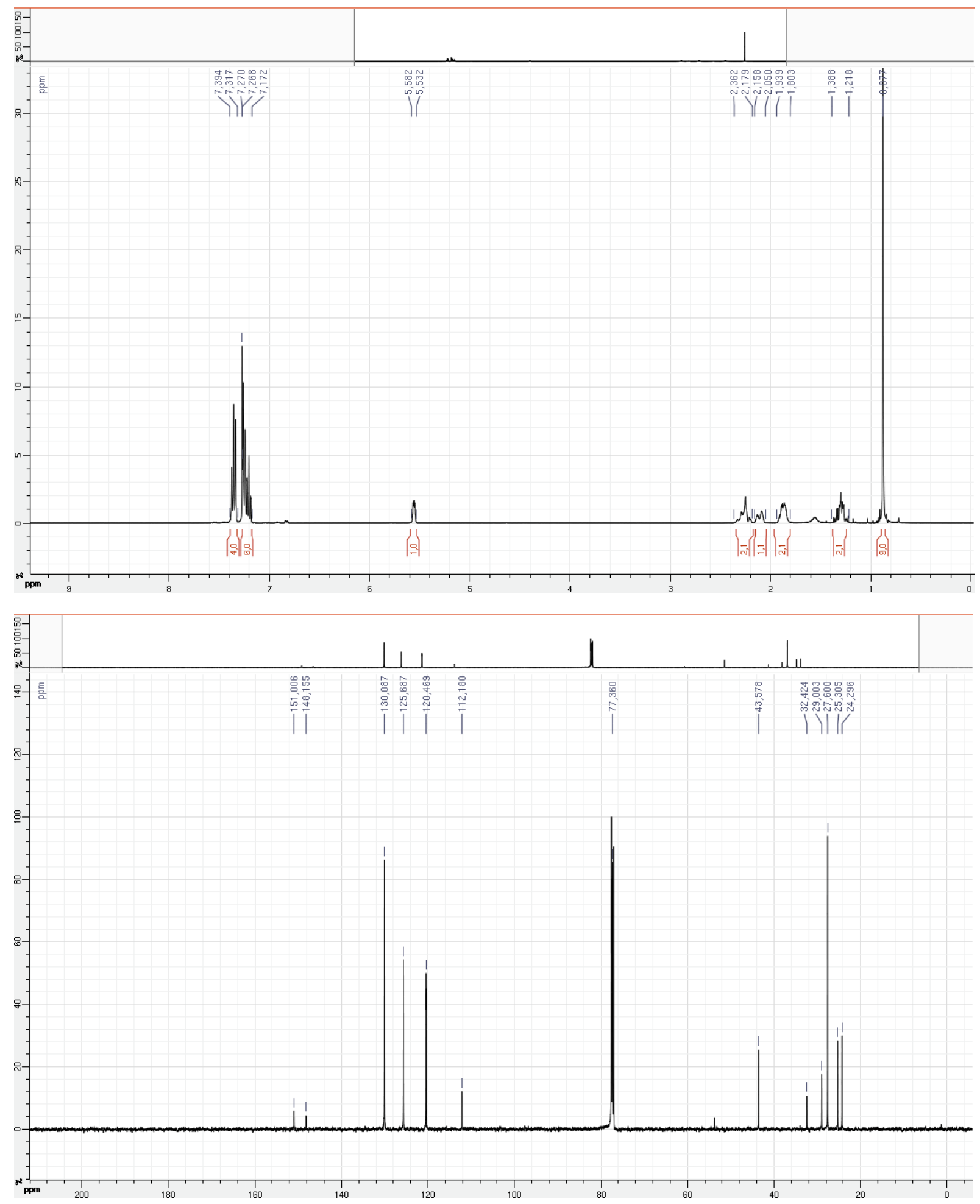

17 


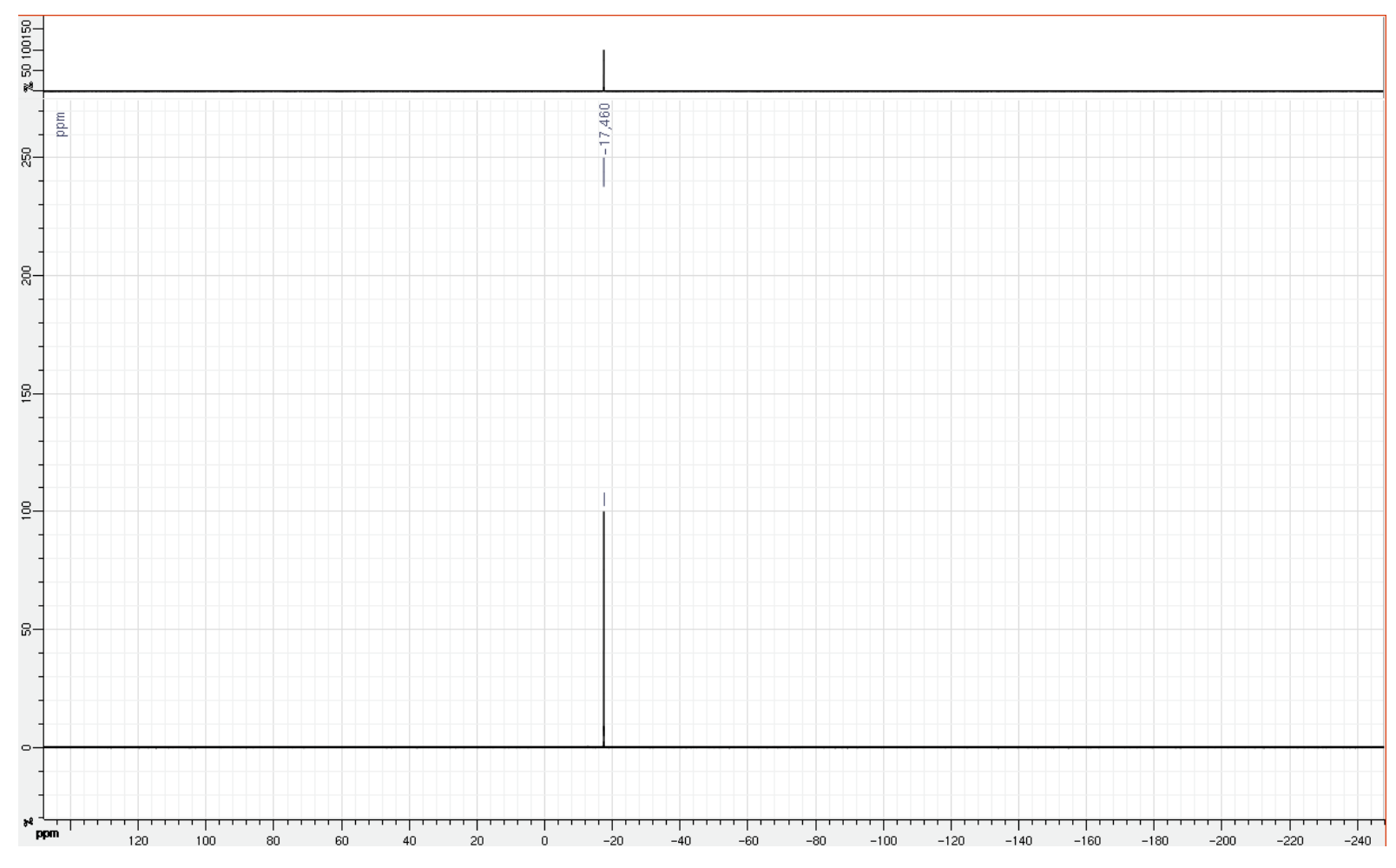




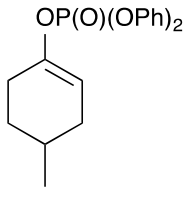

5
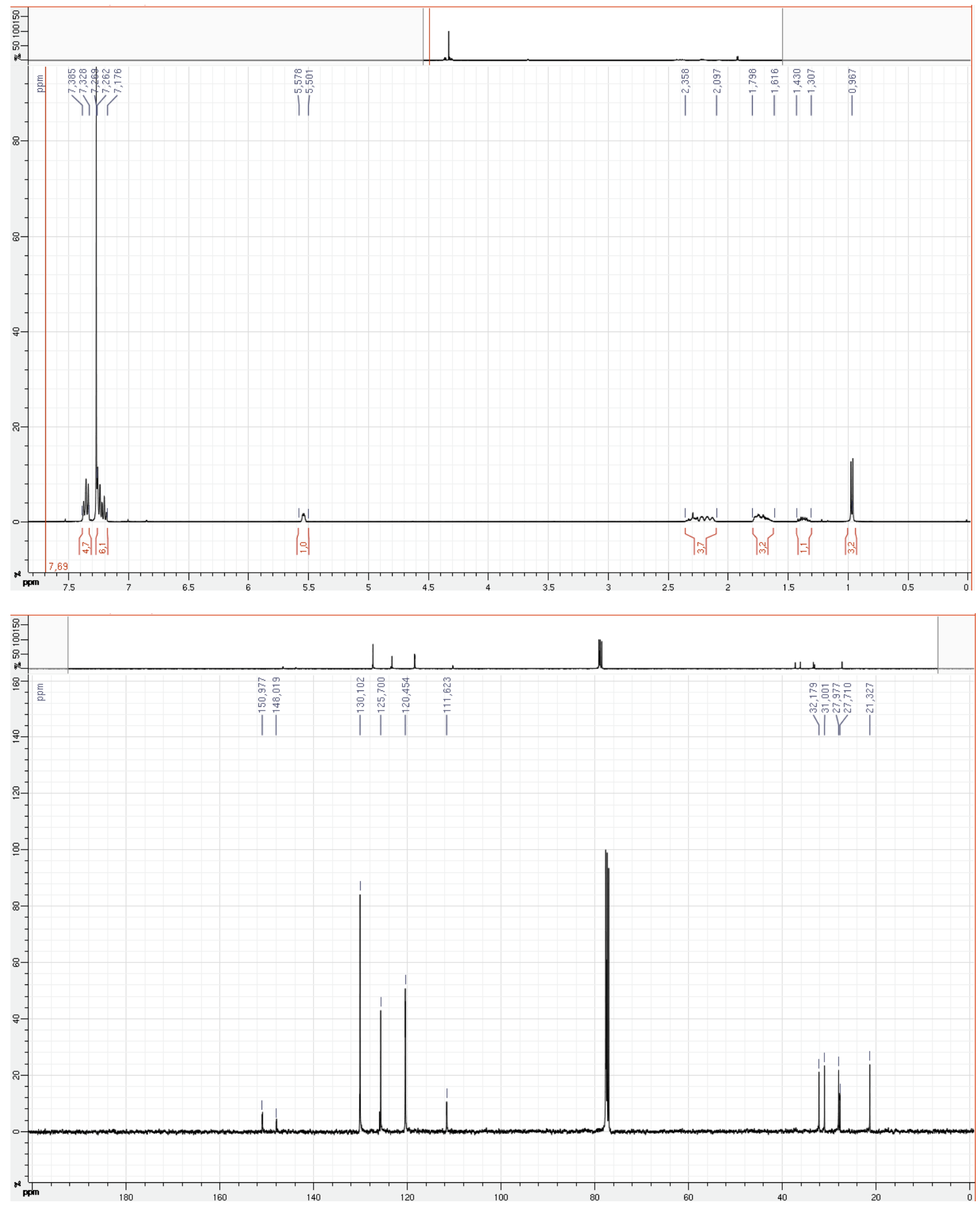


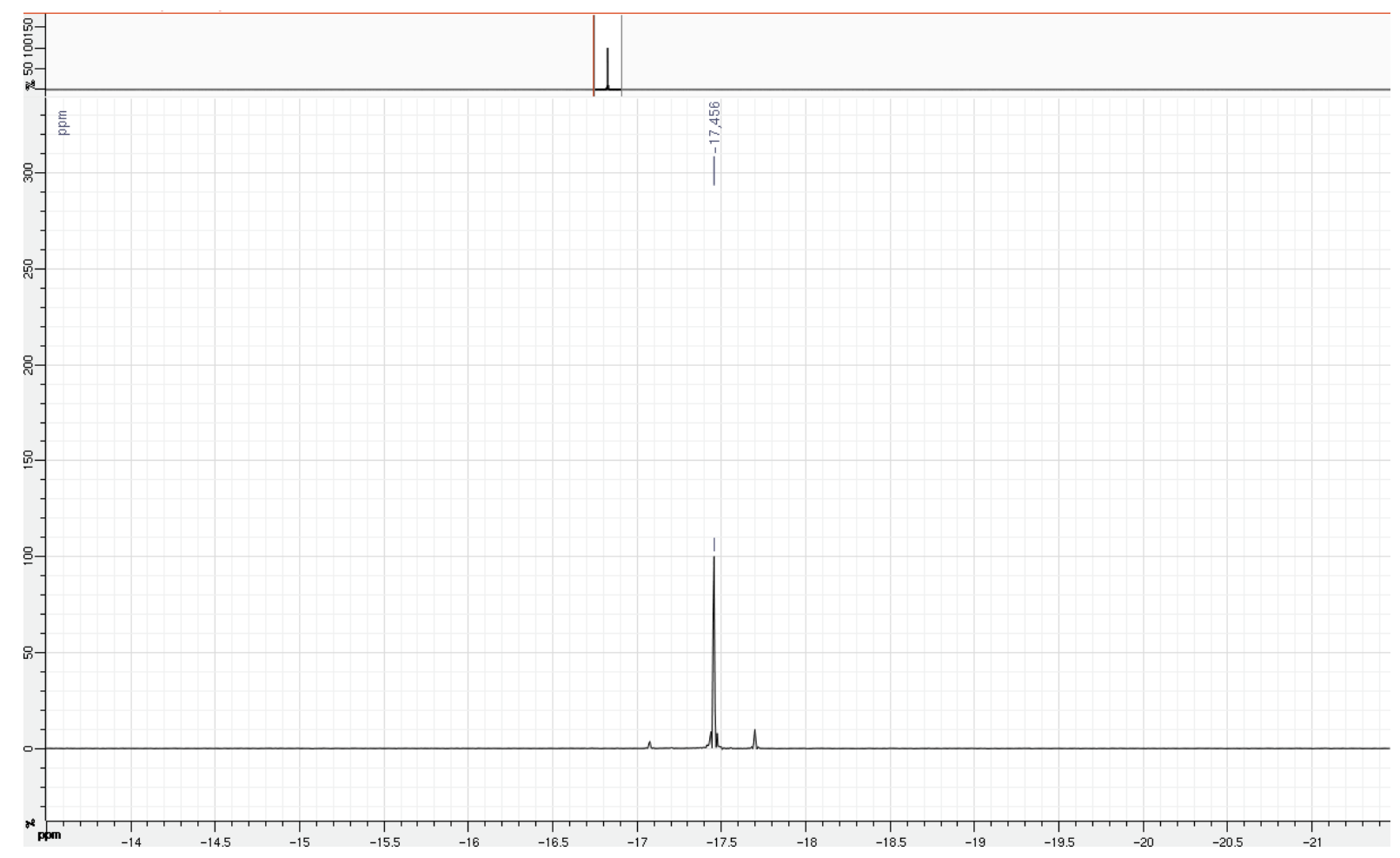

20 

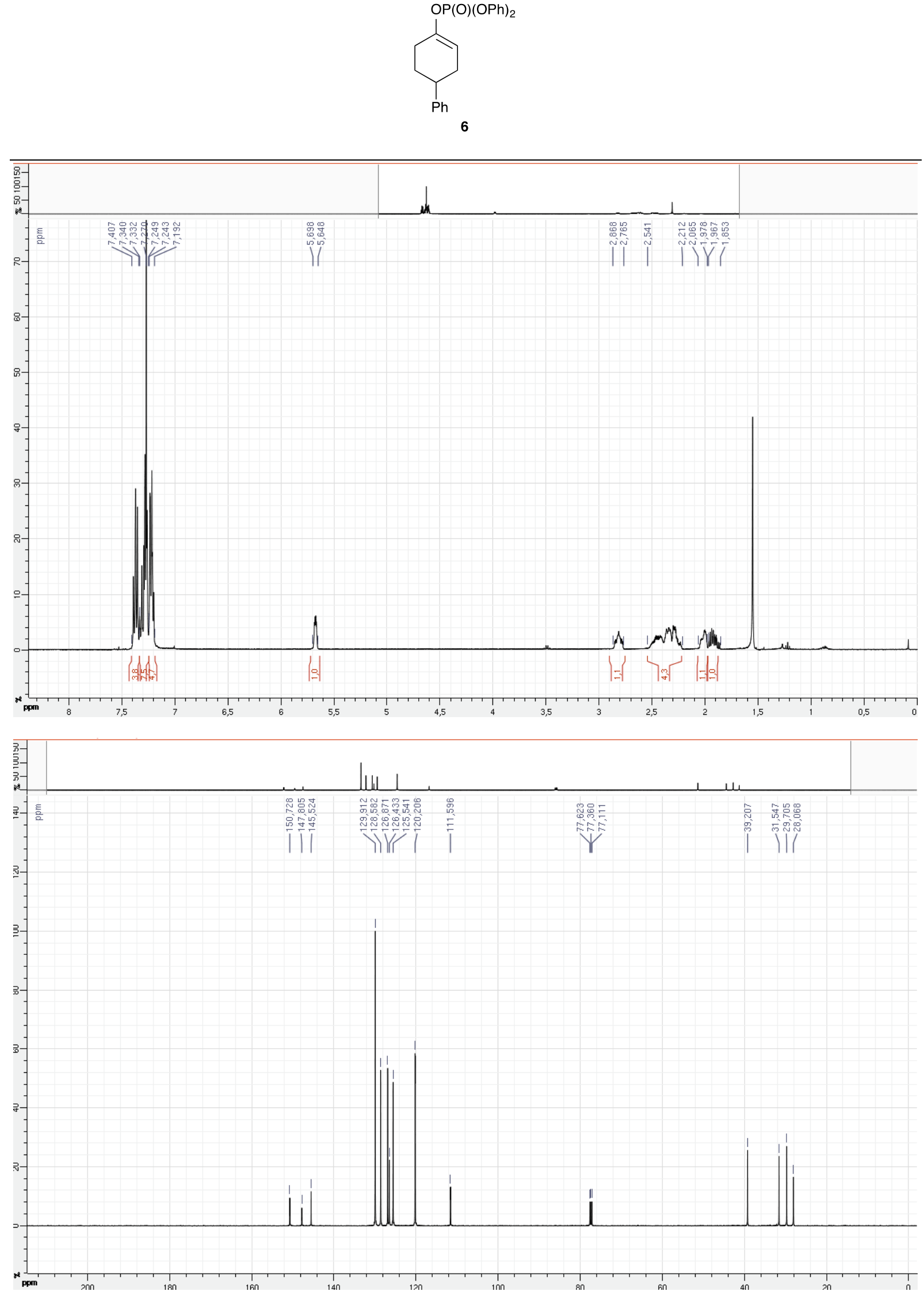


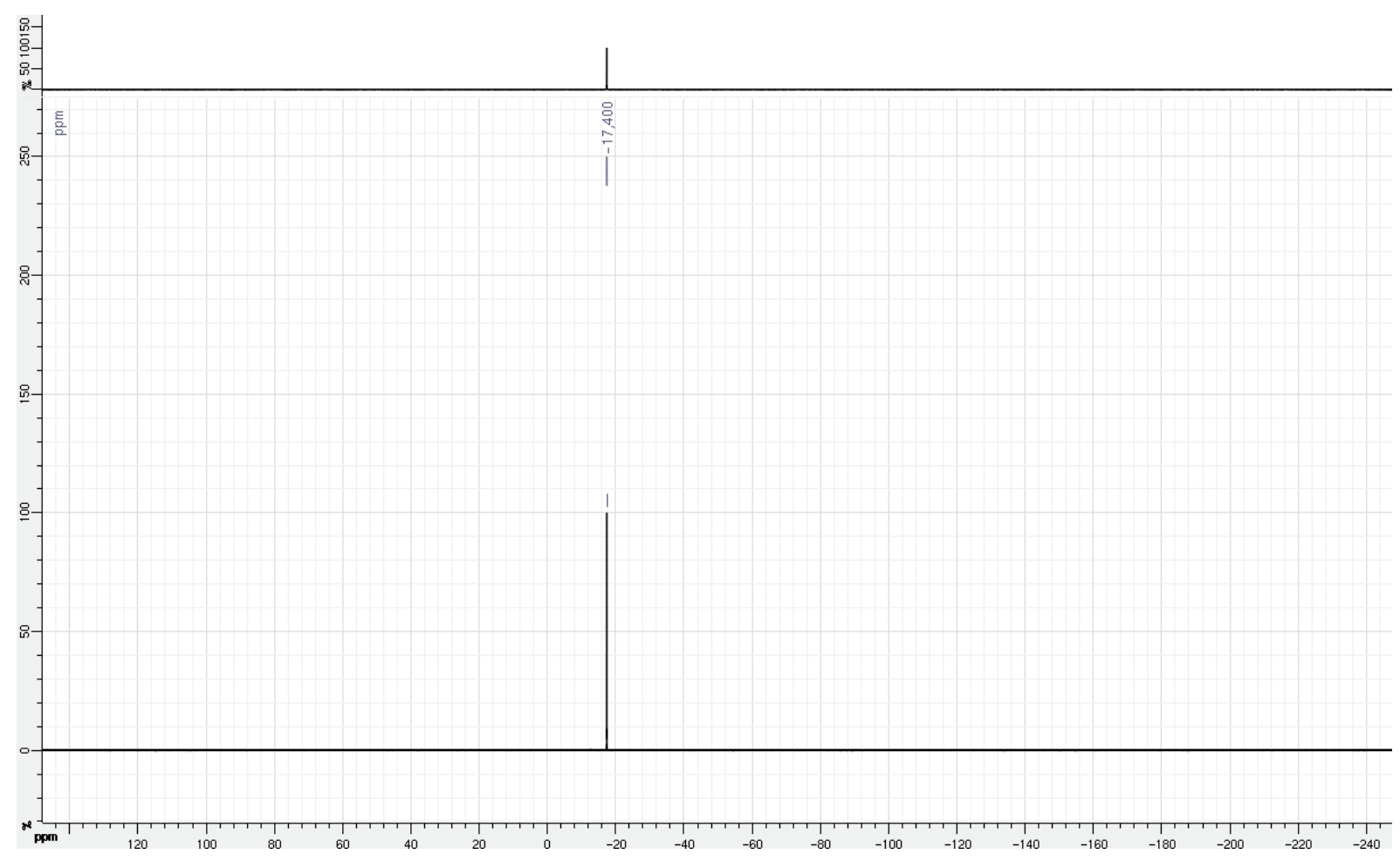



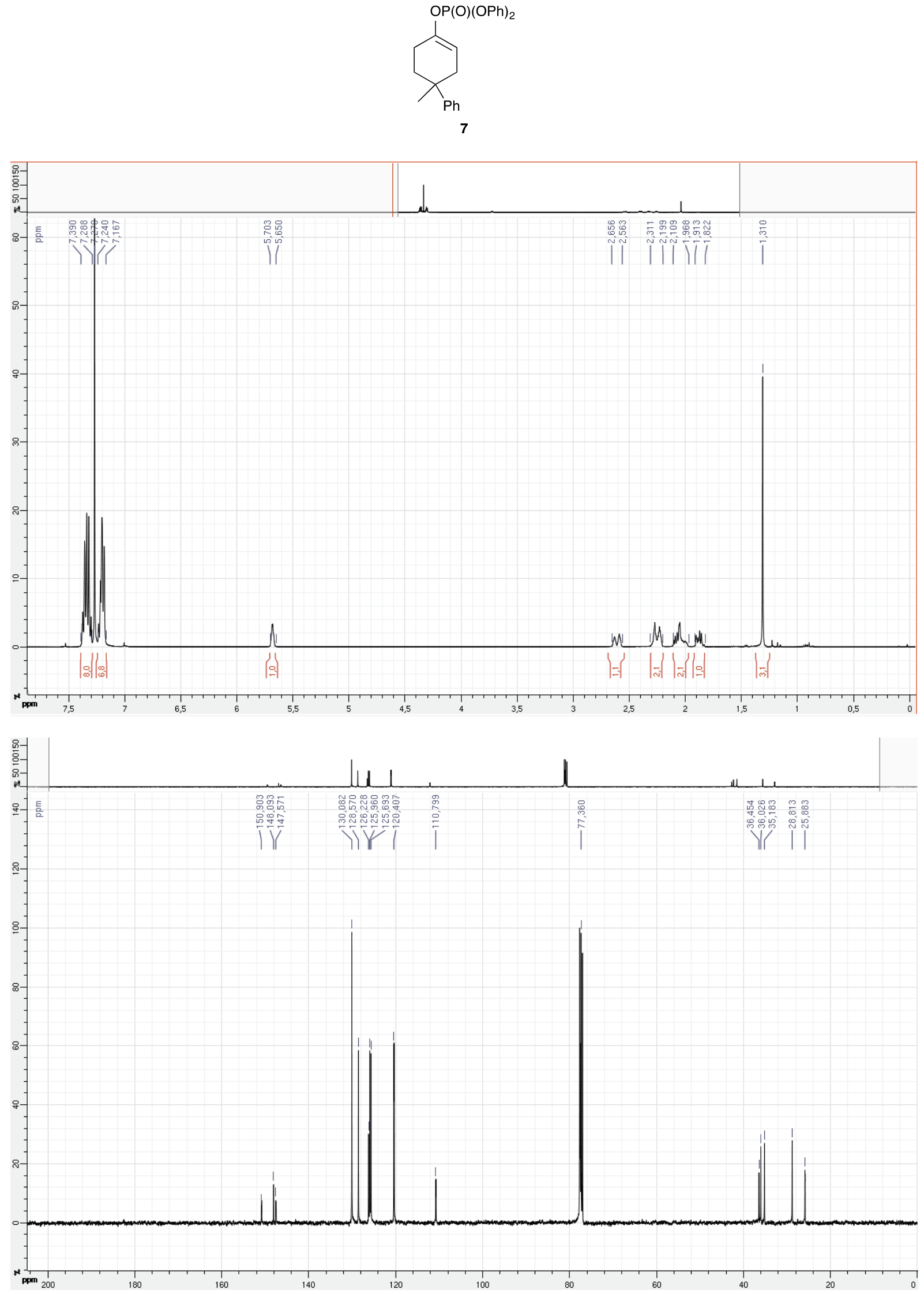


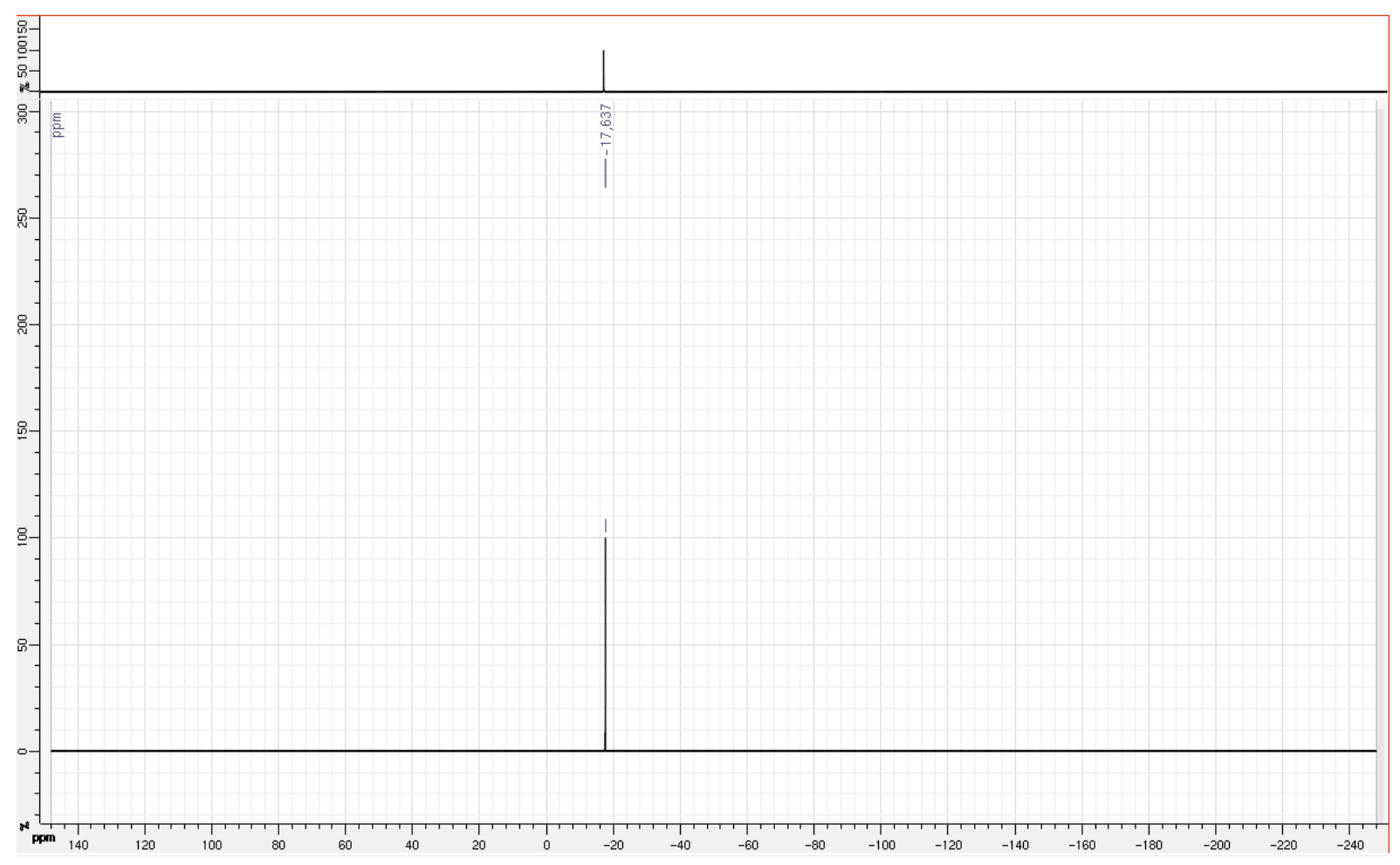


<smiles>[18O]OC1=CCC(O[18OH])CC1</smiles>
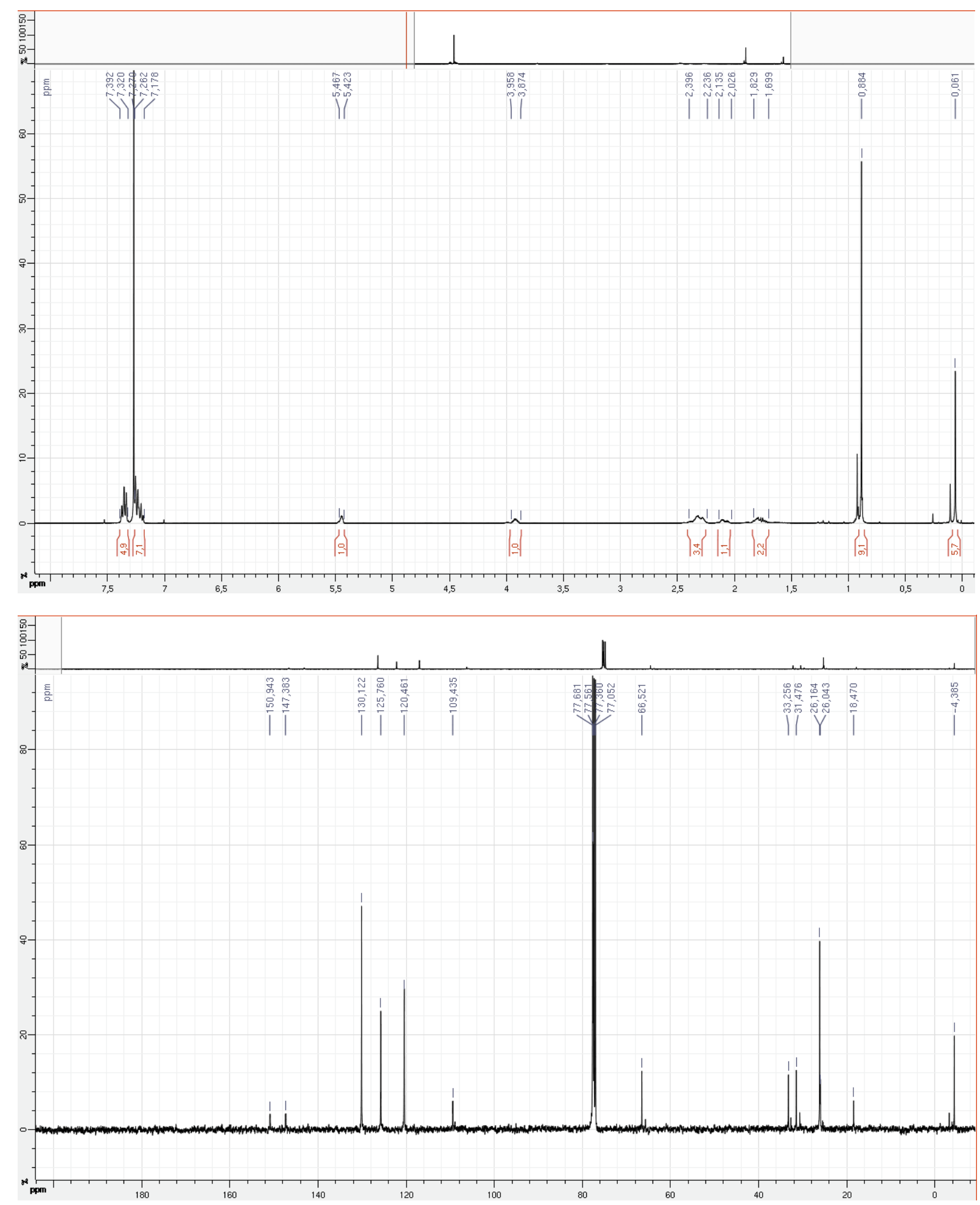

25 


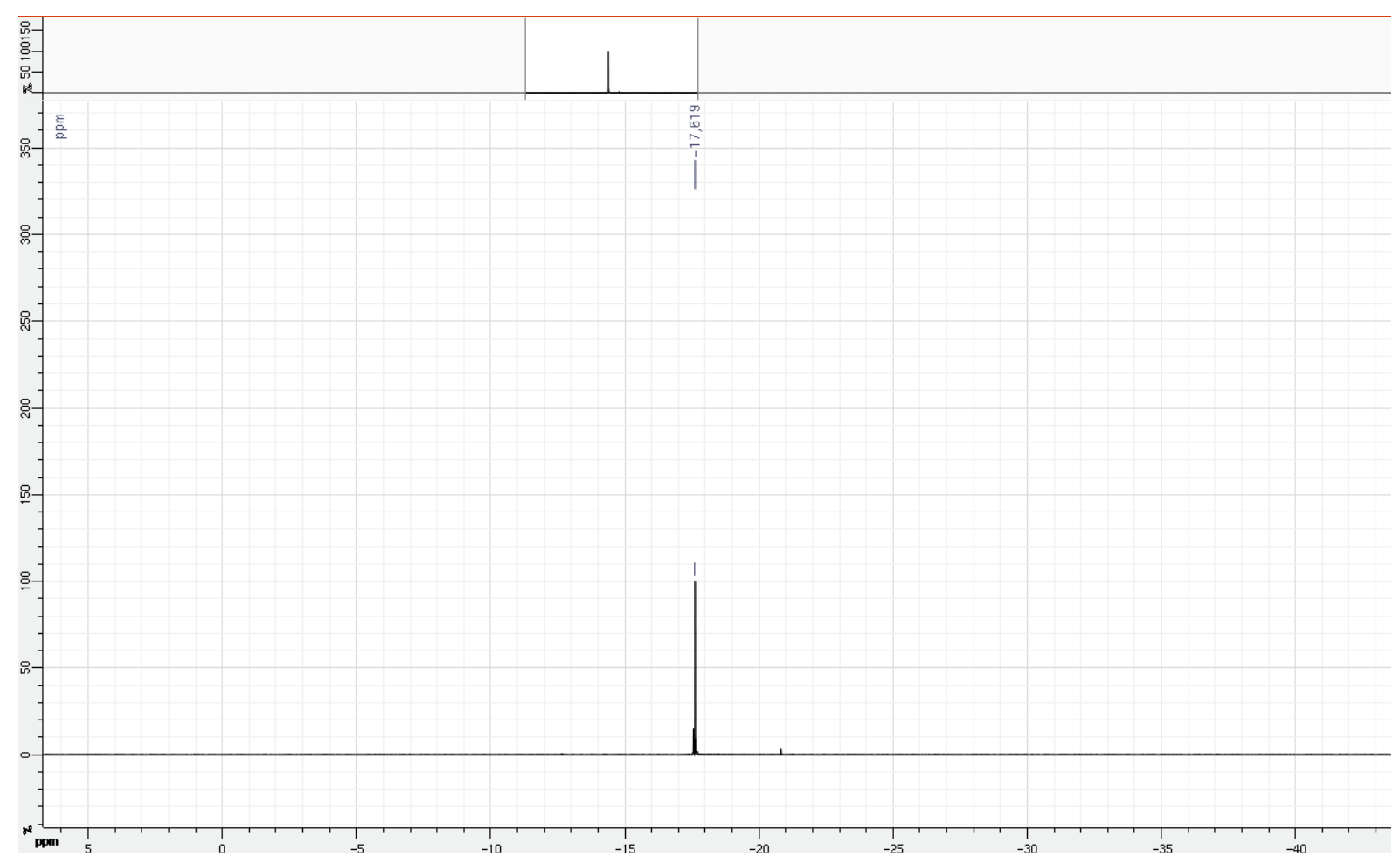




$$
\begin{array}{r}
b^{5} \\
\hline \\
\hline
\end{array}
$$




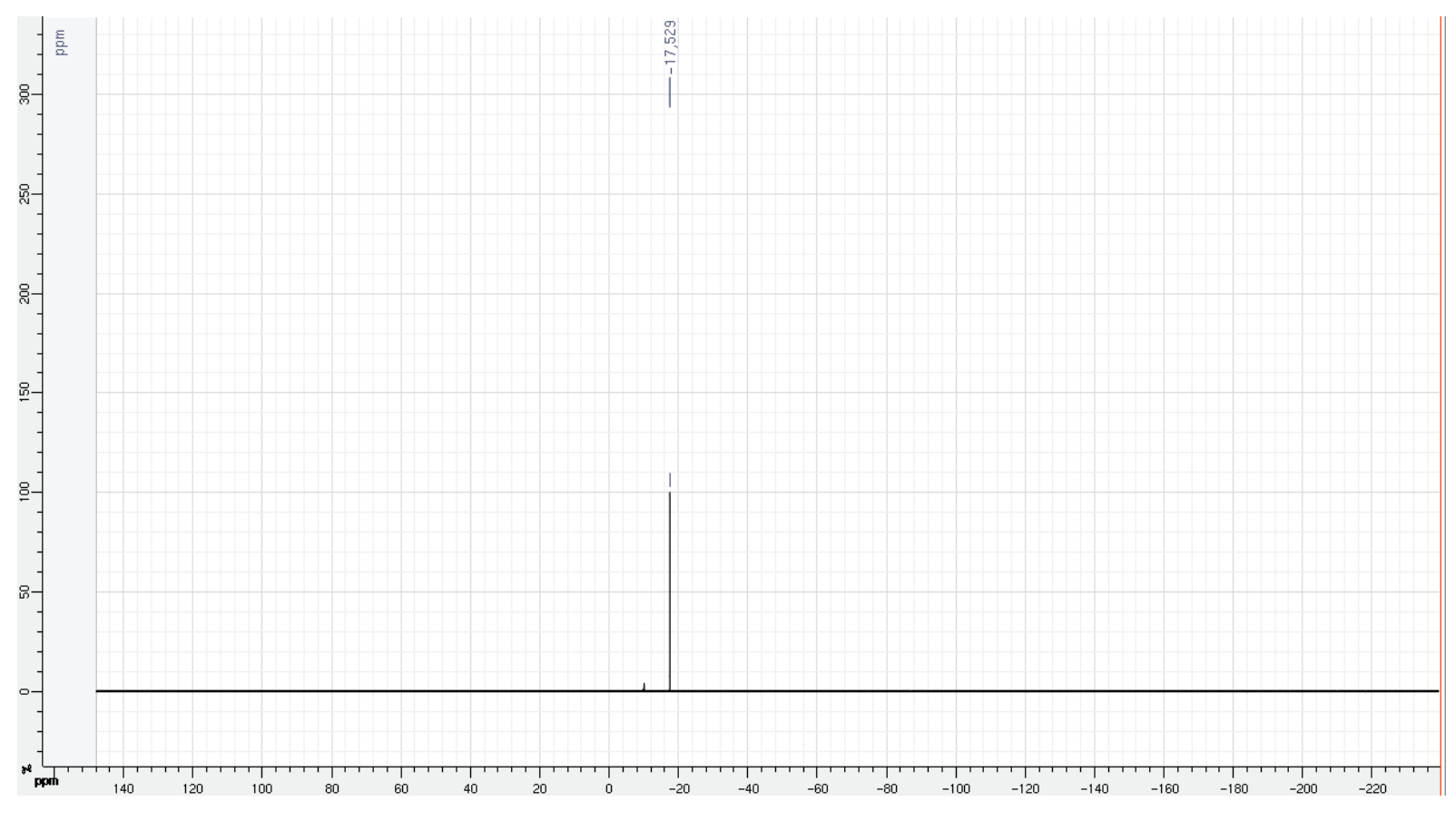



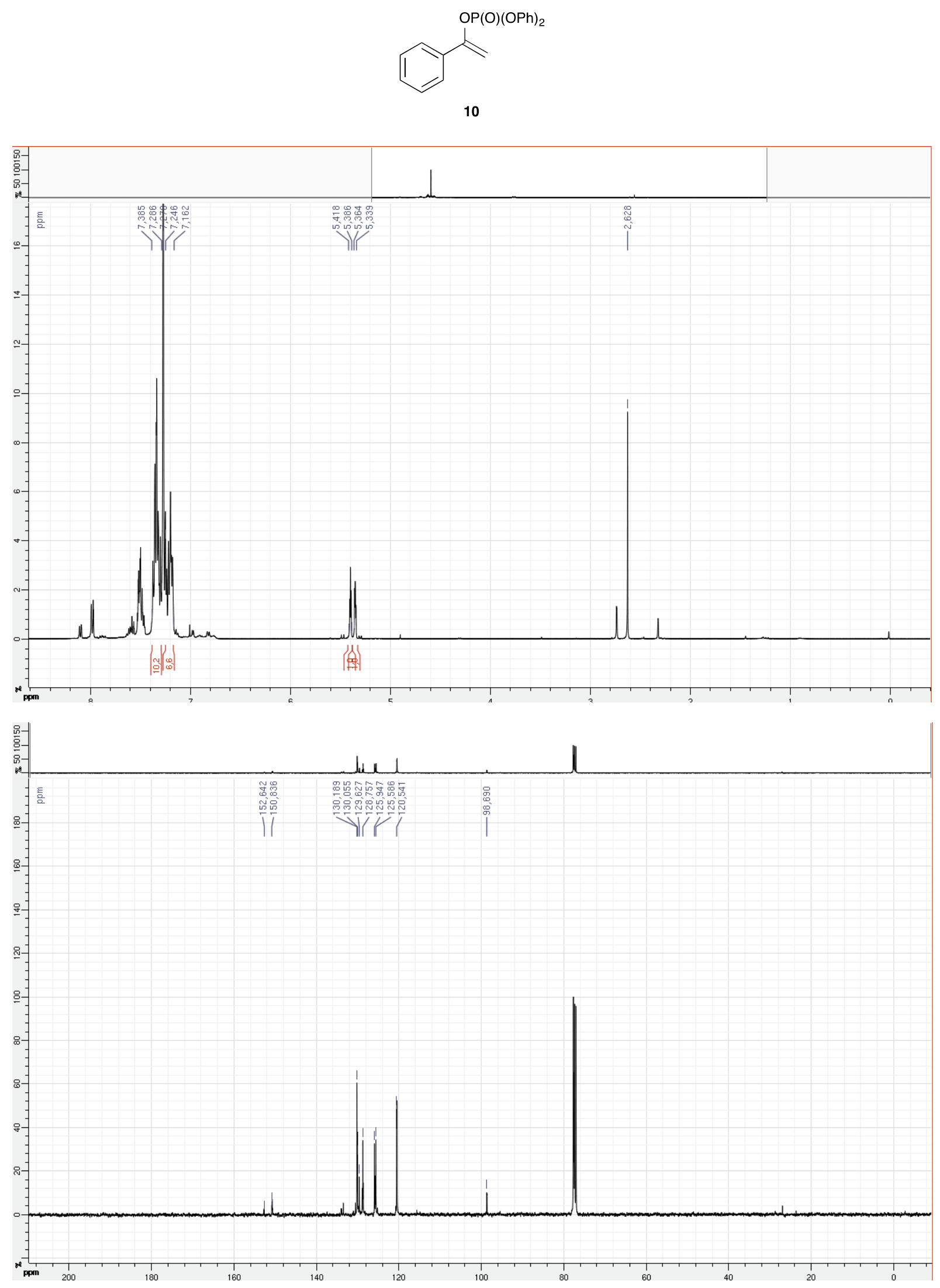


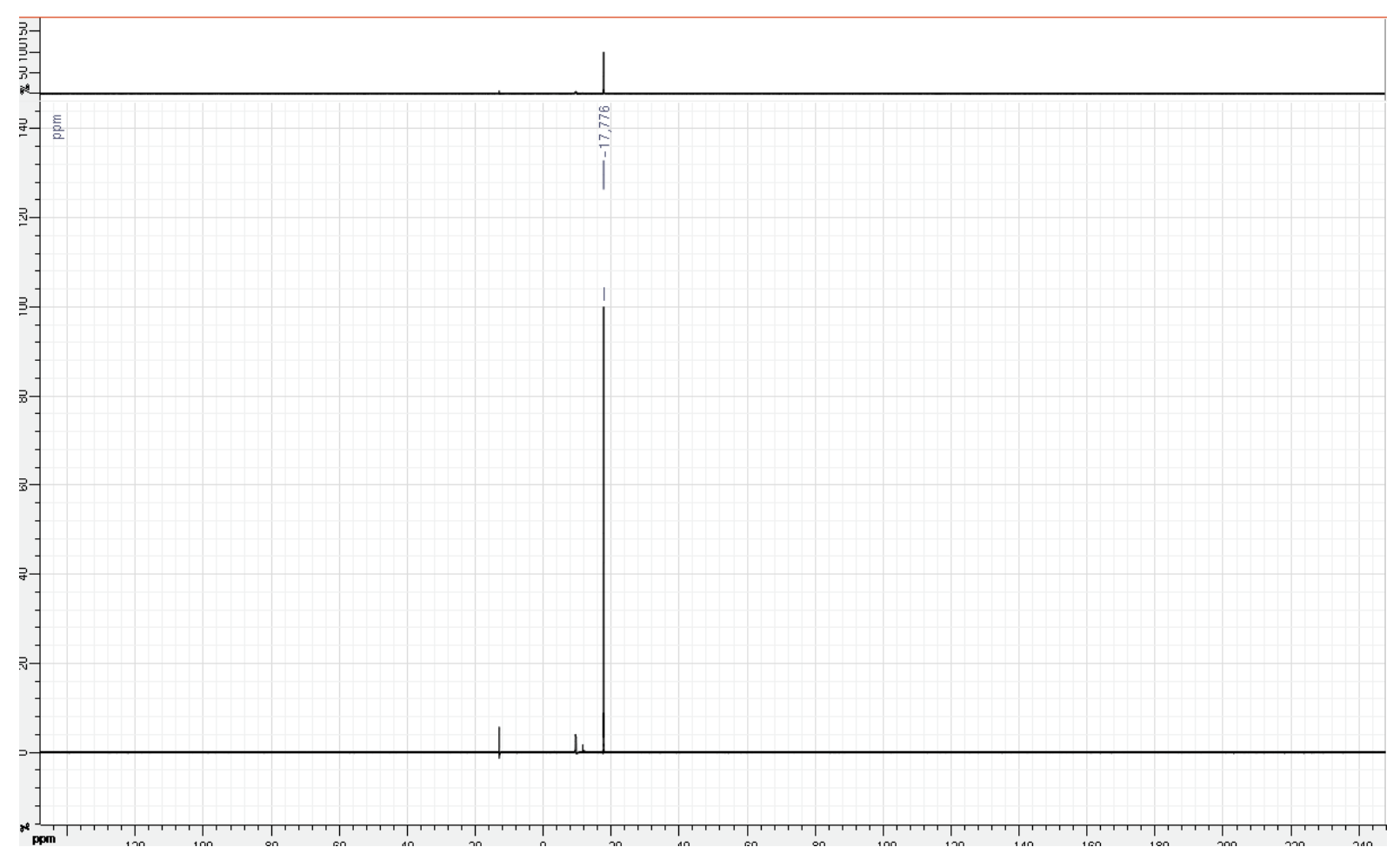


<smiles>C=C(O[PH2+]C(=O)c1ccccc1)c1ccc(Br)cc1</smiles>

11
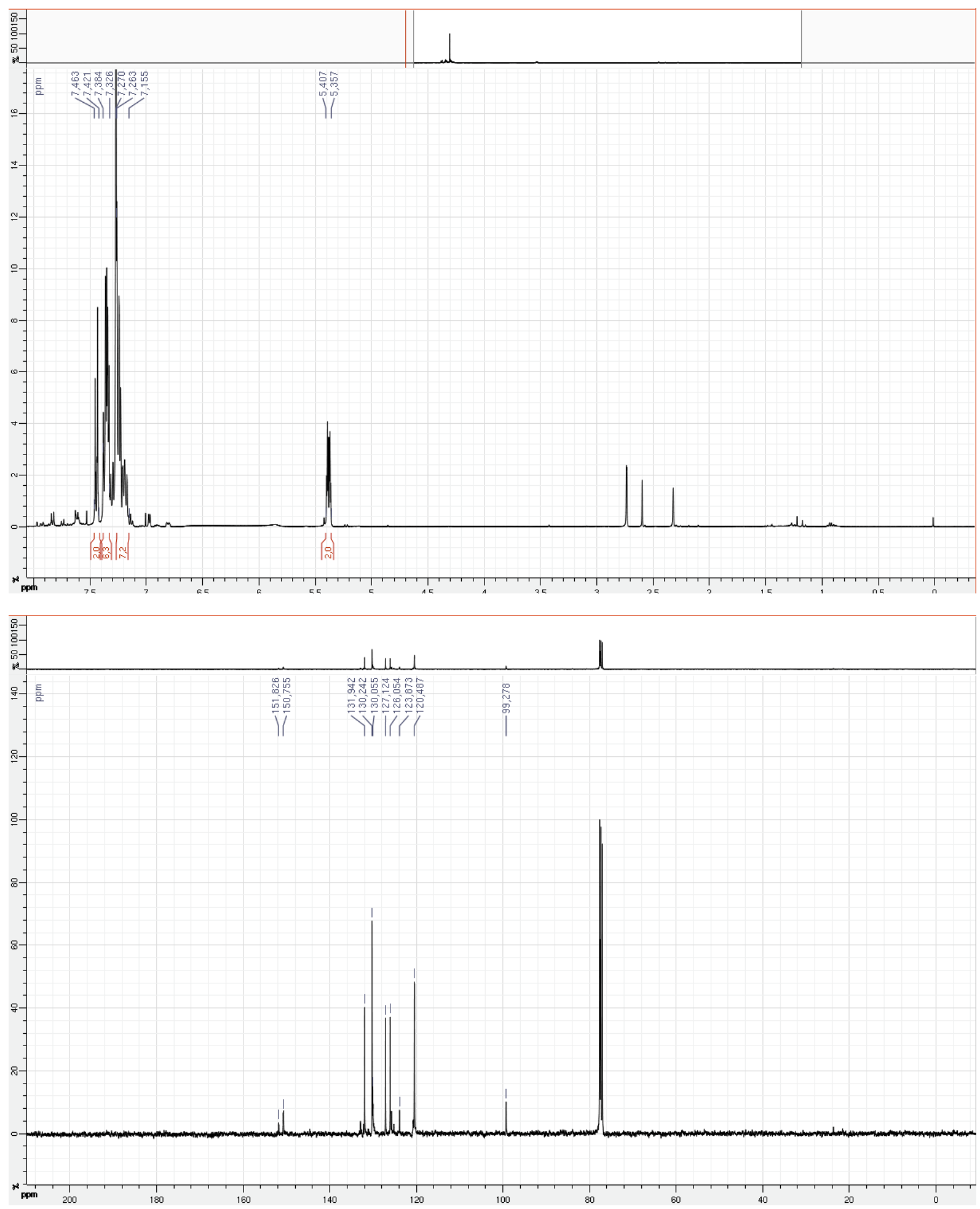

31 


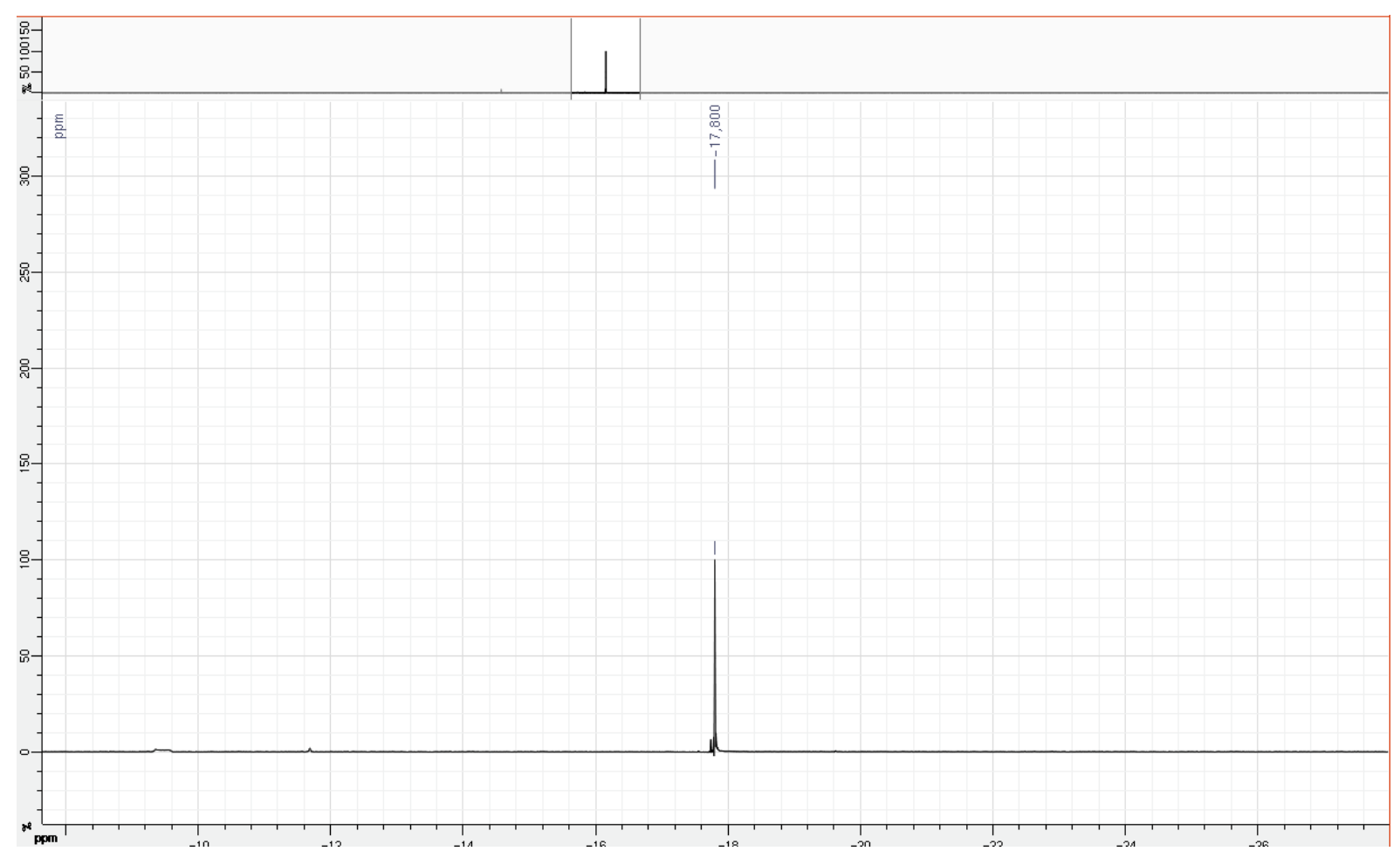



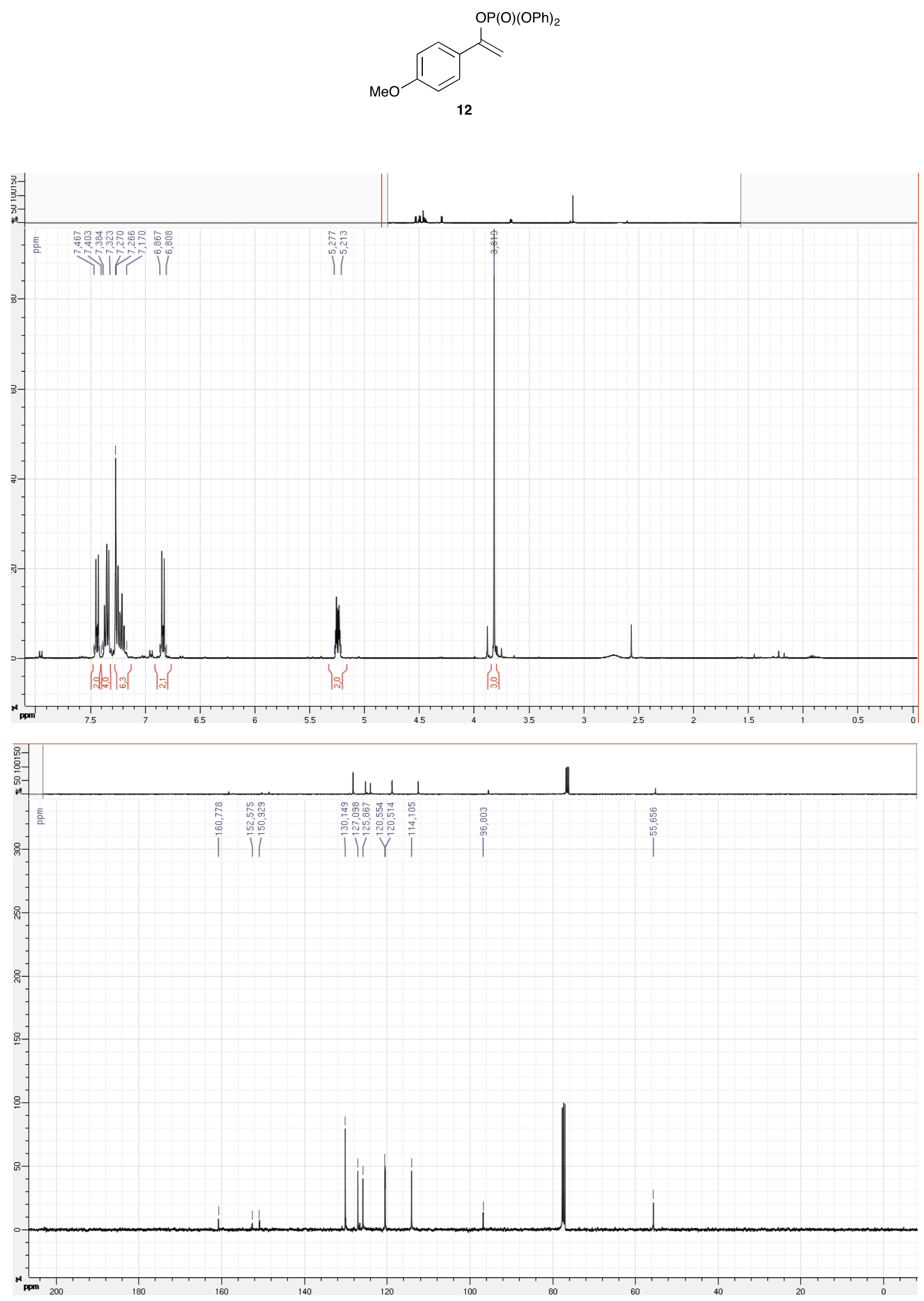


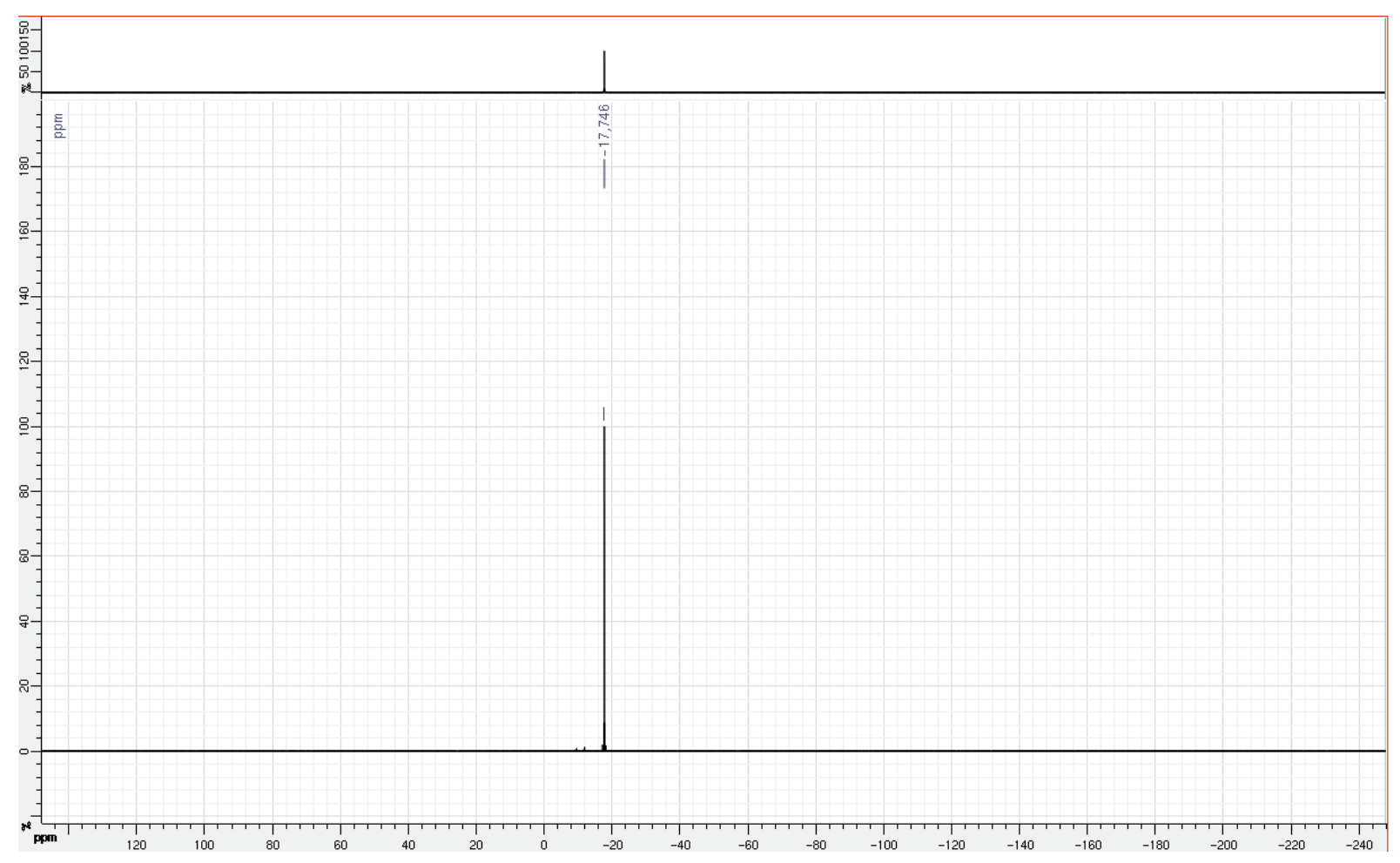


<smiles>C=C(O[OH+]c1ccccc1)c1ccc(C#N)cc1</smiles>
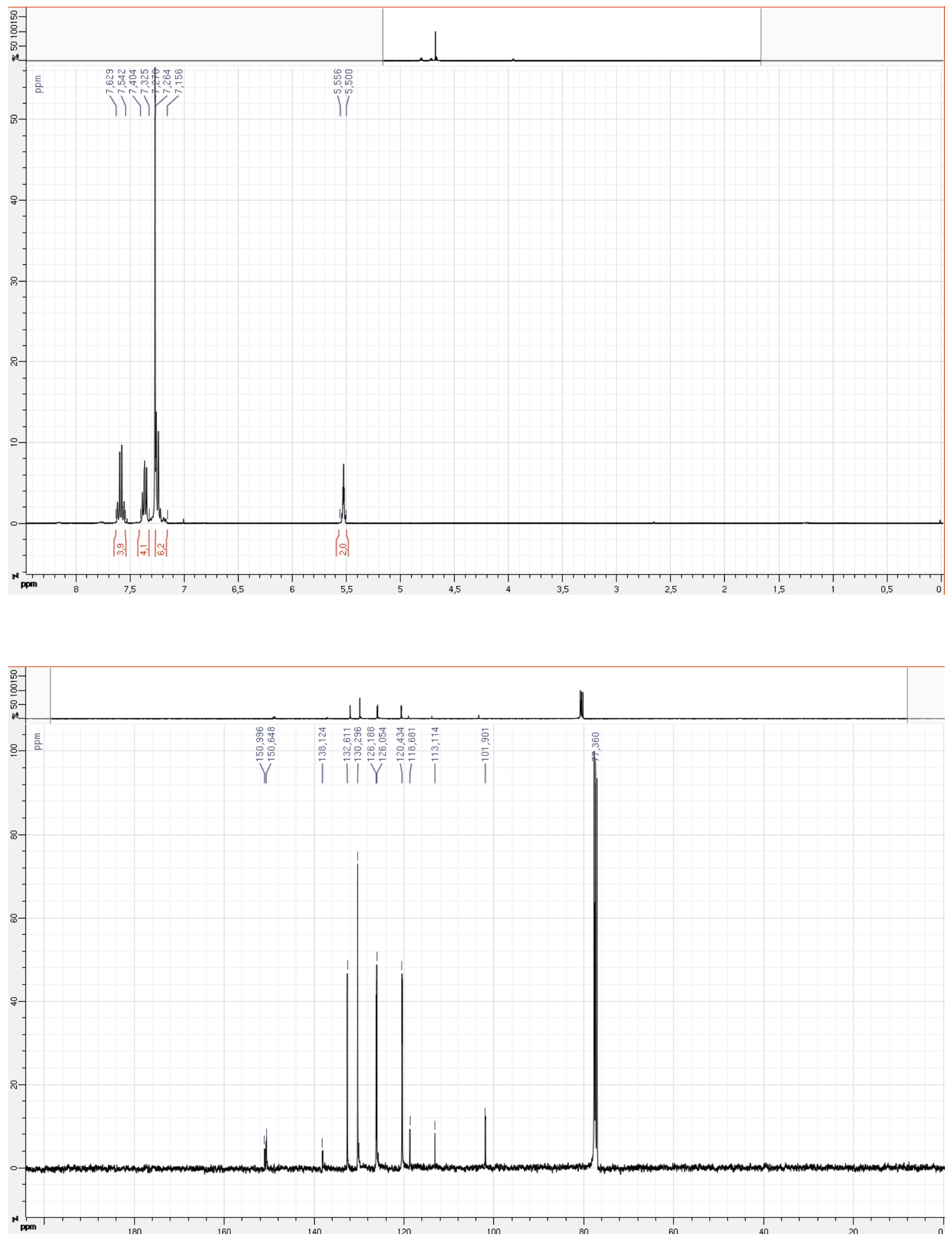

35 


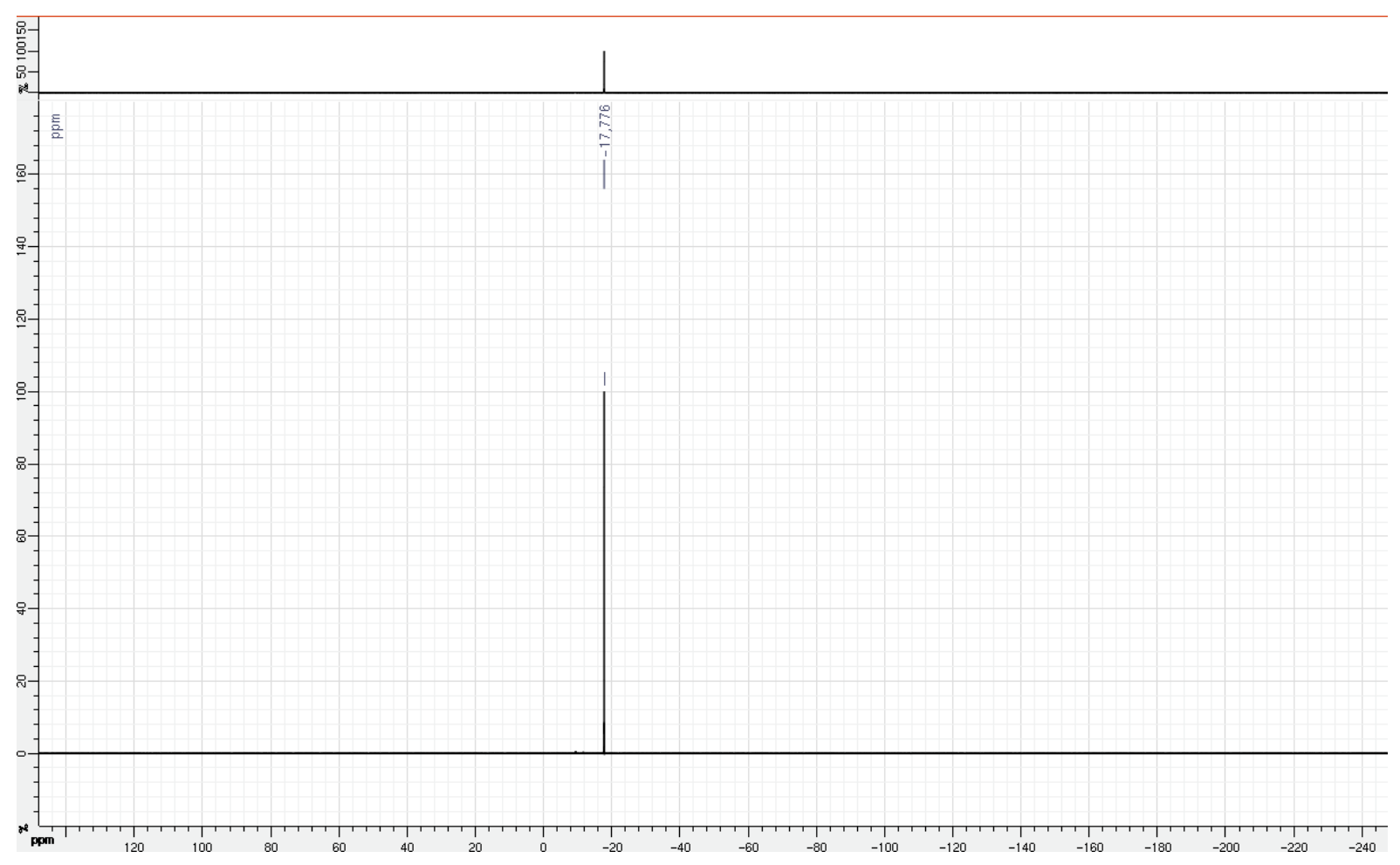



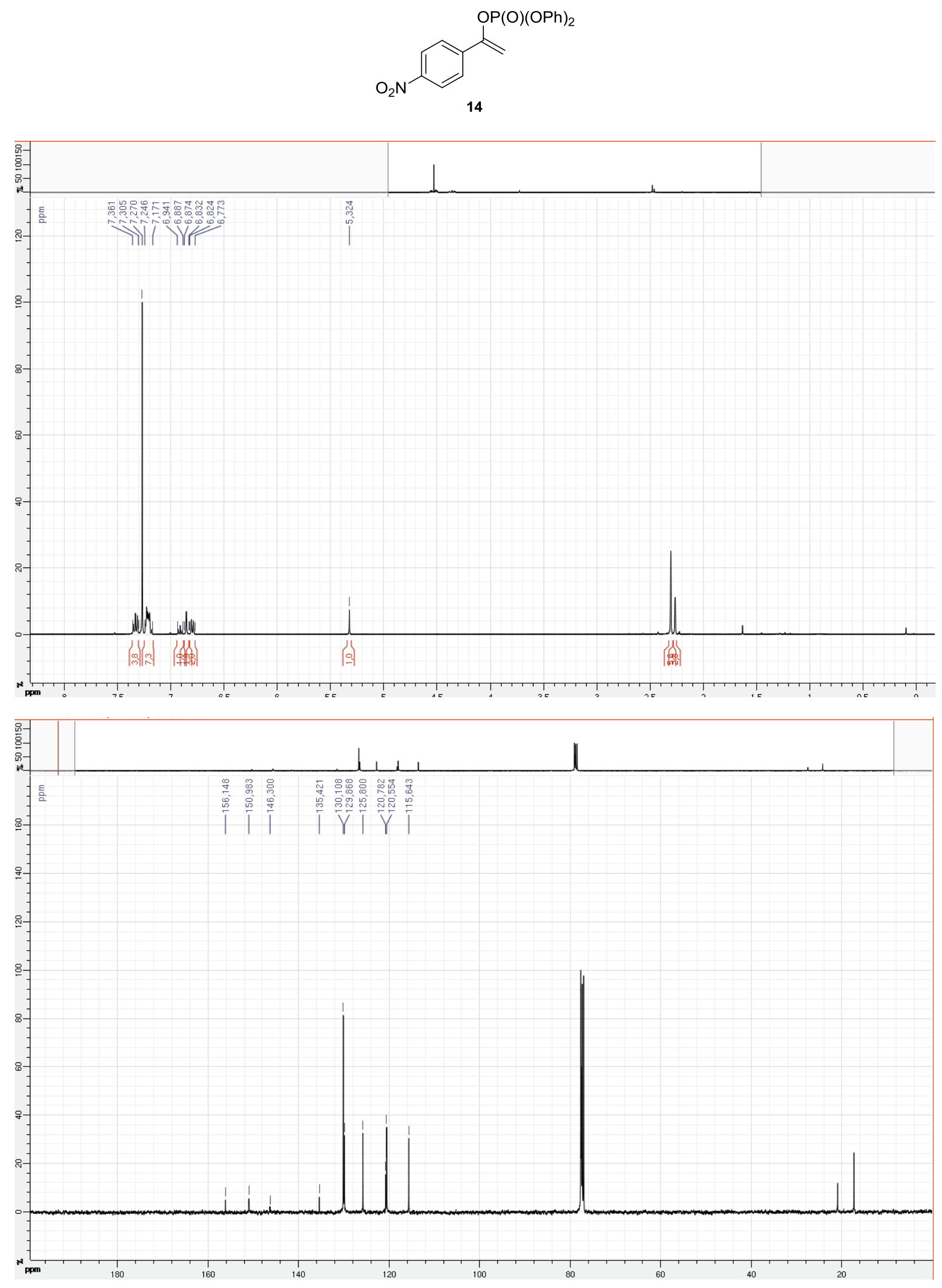


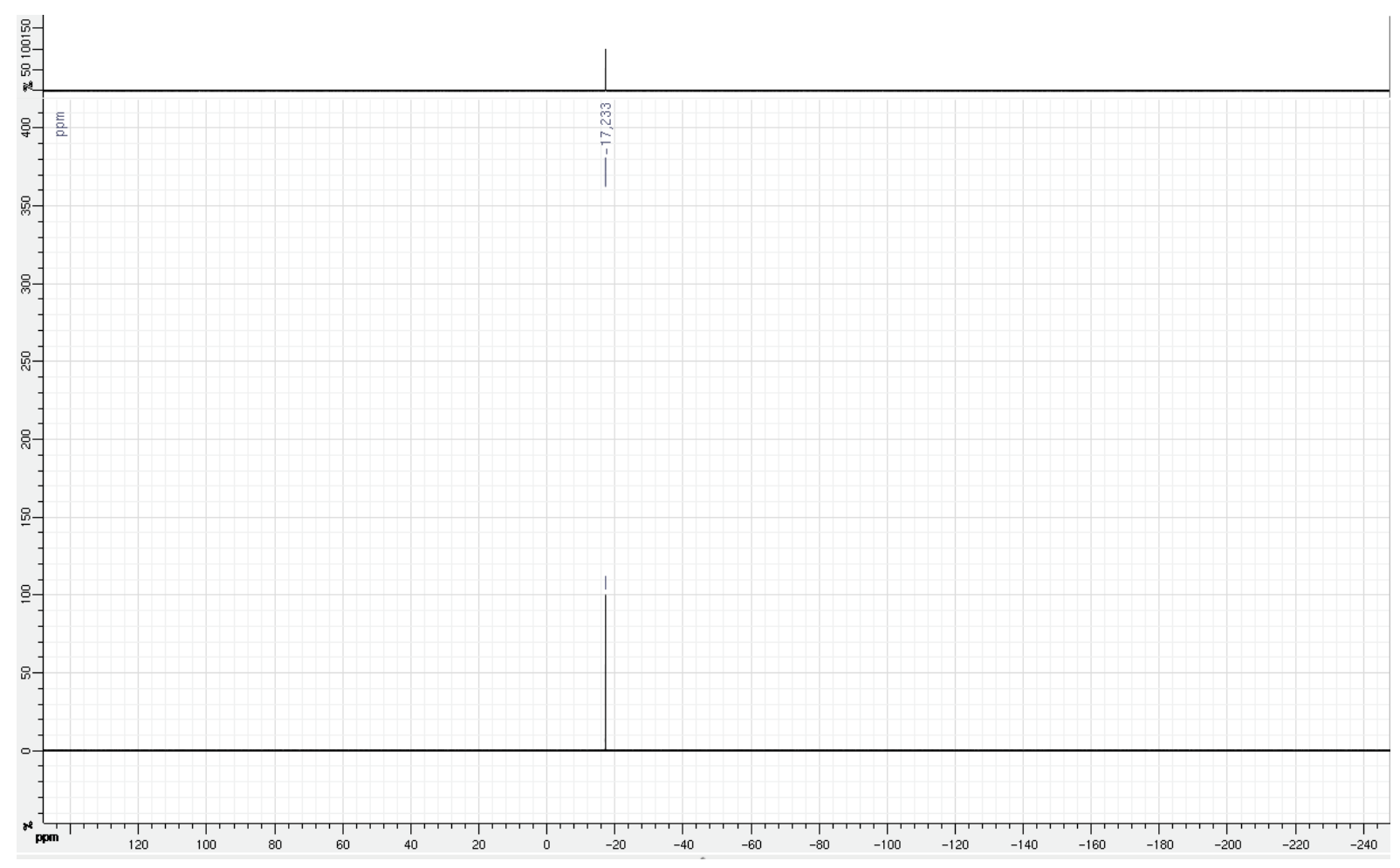




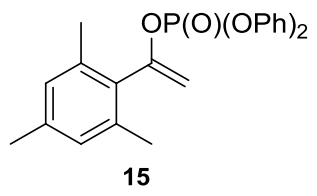
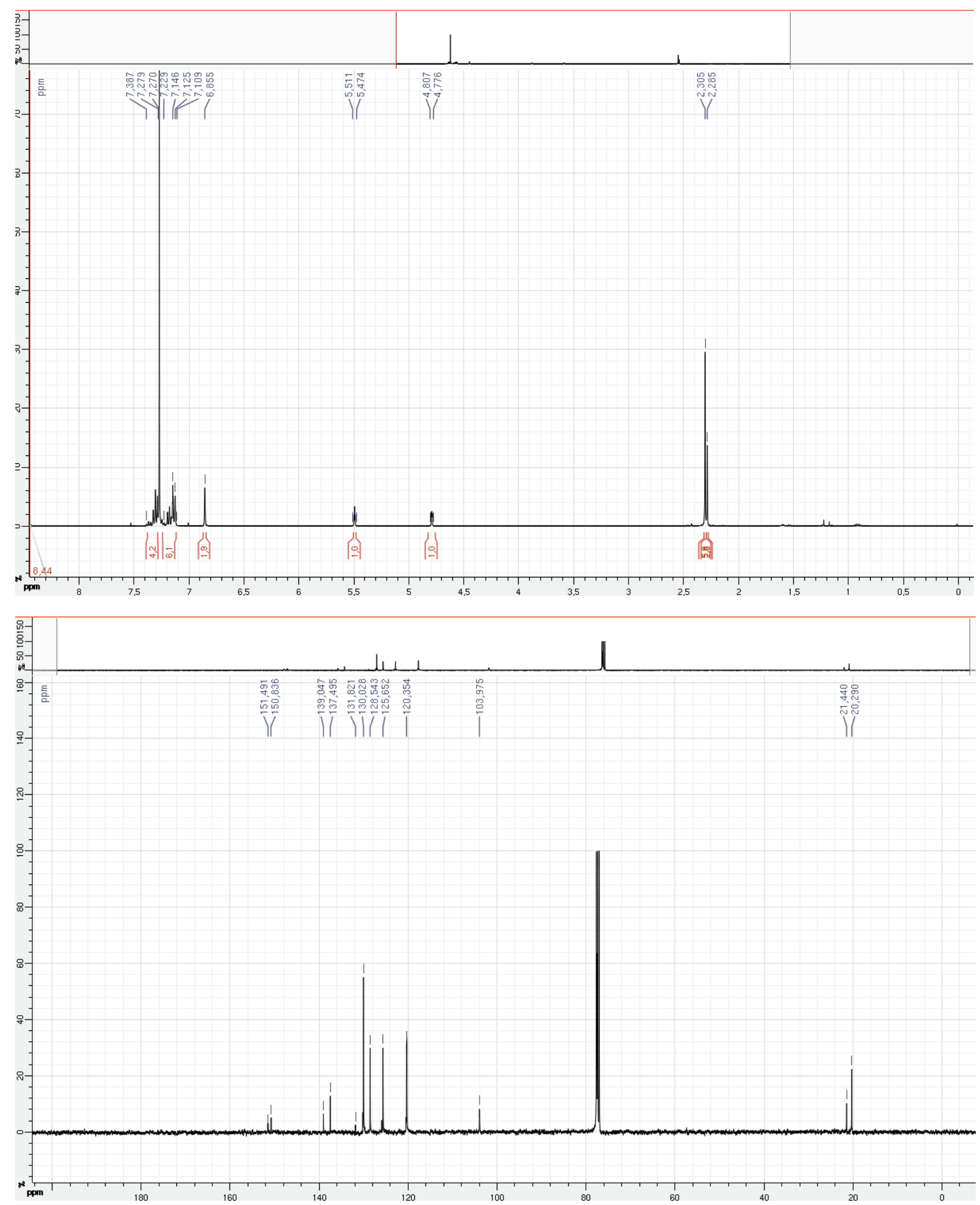

39 


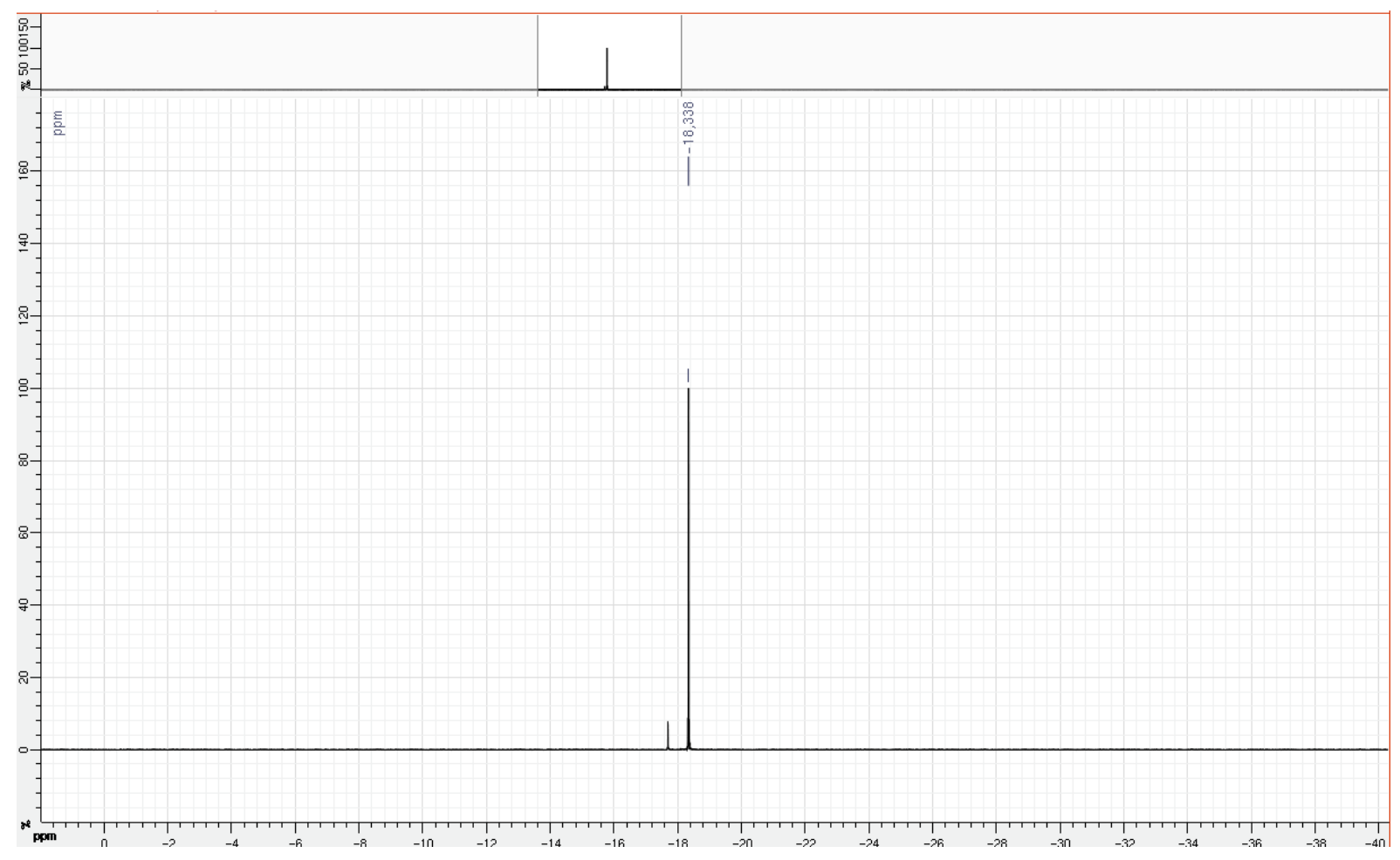





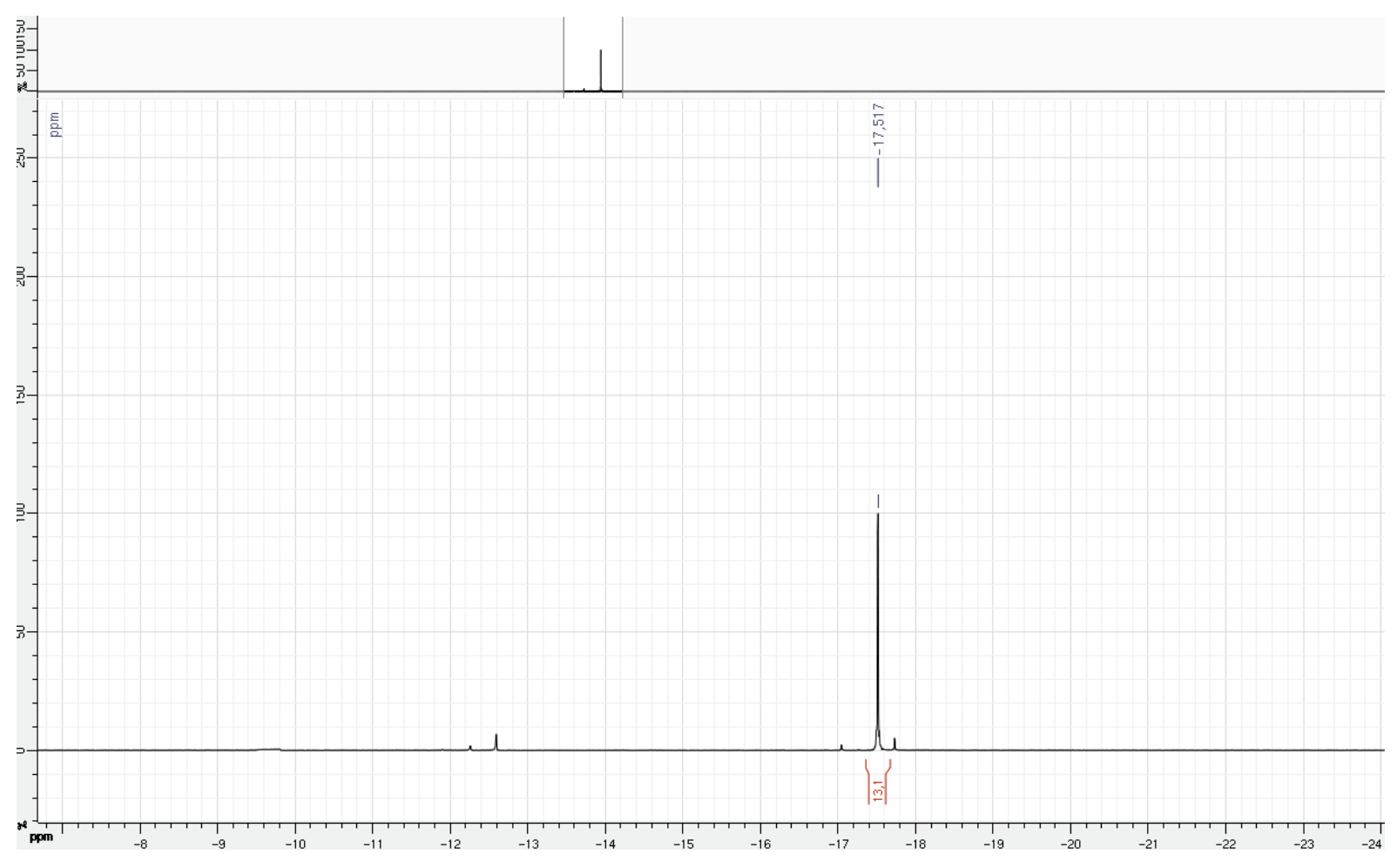




\section{References}

1. D. D. Perrin and W. L. F. Armarego, Purification of Laboratory Chemicals; Pergaman: Oxford; 1988.

2. B. E. Love and E. G. Jones, J. Org. Chem., 1999, 64, 3755.

3. (a) H. E. Zimmerman and G. Jones II, J. Am. Chem. Soc., 1970, 92, 2753; (b) W. R. Hardie, J. Hidalgo, I. F. Halverstadt, and R. E. Allen, J. Med. Chem., 1966, 9, 127.

4. M. C. Carreño, A. Urbano, and C. Di Vitta, J. Org. Chem., 1998, 63, 8320.

5. P. R. Guzzo, R. N. Buckle, M. Chou, S. R. Dinn, M. E. Flaugh, A. D. Kiefer Jr., K. T. Ryter, A. J. Sampognaro, S. W. Tregay, and Y.-C. Xu, J. Org. Chem., 2003, 68, 770.

6. (a) K. Takai, M. Sato, K. Oshima, and H. Nozaki, Bull. Chem. Soc. Jpn., 1984, 57, 108; (b) O. Lagerlund, M. L. H. Mantel, and M. Larhed, Tetrahedron, 2009, 65, 7646.

7. A. L. Hansen, J.-P. Ebran, M. Ahlquist, P.-O. Norrby, and T. Skrydstrup, Angew. Chem. Int. Ed., 2006, 45, 3349.

8. A. L. Hansen, J.-P. Ebran, T. M. Gøgsig, and T. Skrydstrup, Chem. Commun., 2006, 4137.

9. P. H. Lee, D. Kang, S. Choi, and S. Kim, Org. Lett., 2011, 13, 3470. 